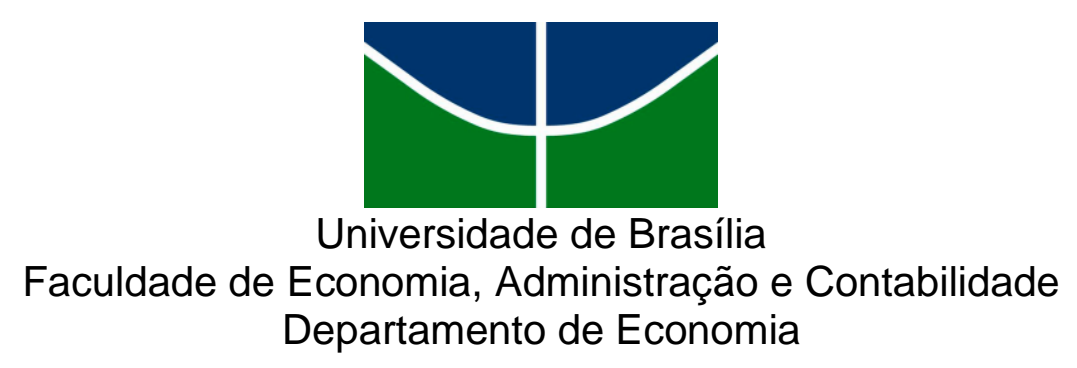

POLÍTICAS PÚBLICAS DO DISTRITO FEDERAL:

UMA INTERFACE NECESSÁRIA COM O EMPREENDEDORISMO?

Brasília, 2016 
Wildston Silva de Freitas

POLÍTICAS PÚBLICAS DO DISTRITO FEDERAL:

UMA INTERFACE NECESSÁRIA COM O EMPREENDEDORISMO?

Dissertação apresentada ao Departamento de Economia como requisito parcial à obtenção do título de Mestre em Gestão e Economia do Setor Público.

Professor Orientador: Prof Dr Antônio Nascimento Júnior

Brasília, 2016 
Wildston Silva de Freitas

\title{
POLÍTICAS PÚBLICAS DO DISTRITO FEDERAL: UMA INTERFACE NECESSÁRIA COM O EMPREENDEDORISMO?
} A Comissão Examinadora, abaixo identificada, aprova o a Dissertação do Curso de
Mestre em Gestão e Economia do Setor Público do aluno

Aprovada em 30 de dezembro de 2016

Prof. Dr. Antônio Nascimento Júnior

Membro Interno

Universidade de Brasília (UnB)

Prof. Dr. Roberto de Goes Ellery Junior

Membro Interno

Universidade de Brasília (UnB)

\author{
Dr. Adolfo Sachsida \\ Membro Externo \\ Instituto de Pesquisa Econômica Aplicada (IPEA)
}


DEDICATÓRIA 
Dedico este trabalho aos meus pais Luciano (in memorian) e Francisca, por toda dedicação e força ao longo da minha vida. A minha esposa Sintia, pela paciência e força nos momentos difíceis e aos nossos filhos Ana Clara, Ana Catarina, Mariana, Murilo, Bernardo e Leonardo. 


\section{AGRADECIMENTOS}

Agradeço em especial ao meu orientador Professor Antônio Nascimento Júnior pelo incentive e apoio.

A todos os professores que compartilharam seus conhecimentos ao longo do curso. A Deus Pai, Filho e Espírito Santo por Quem tudo foi criado. 


\section{RESUMO}

Este estudo tem como objetivo apresentar o Programa Prospera de Microcrédito Produtivo Orientado do Governo do Distrito Federal e sua contribuição para o empreendedorismo no Distrito Federal. O Prospera existe desde 1995 sendo regido por lei complementar com recursos disponíveis para empreendedores formais e informais do Distrito Federal e Entorno. A partir das perspectivas históricas do microcrédito no Brasil e no mundo, apresentamos o Programa, sua peculiaridades e e sua relação com o desenvolvimento empreendedor no Distrito Federal.

Considerando que desenvolvimento local não deve ser apenas pensado sob a ótica ecônomica, mas também sócio-econômica, é importante considerar o problema da necessidade da geração de emprego e renda e as dificuldades enfrentadas por aqueles que empreendem ao se lançarem e manterem no mercado cada vez mais competitivo. Desta forma, o Estado deve atuar no sentido de impulsionar a capacidade produtiva, com a aplicação de políticas públicas voltadas para os empreendedores mais fragilizados, neste caso os informais e os micro e pequenos empresários.

Palavras-chave: Política pública, Microcrédito, Empreendedorismo, Distrito Federal, Prospera, GDF 


\begin{abstract}
This study aims to present the Prospera Governamental Program of Productive and Oriented Microcredit of Federal District (Brazil) and its contribution to entrepreneurship in the Federal District (Brazil). Prospera Program exists since 1995 and it is regulated by a specific law with loans available to both formal and informal entrepreneurs of the Federal District and surrounding Region. From the historical perspectives of microcredit in Brazil and in the world, we present the Program, its peculiarities and its relation with the entrepreneurial development in the Federal District.

Considering that local development should not only be thought from the economic, but also socio-economic aspects, it is important to support the unemployment problem and lack of incomes besides the difficulties faced by those who undertake in the market increasingly competitive. So, Governments must act in order to boost productive capacity, with the application of public policies aimed at the most fragile entrepreneurs, in this case informal and micro and small entrepreneurs.
\end{abstract}

Keywords: Policy, Microcredit, Entrepreneurship, Federal District Government (Brazil), Prospera Program 


\section{LISTA DE TABELAS}

Tabela 1 - Contribuintes Pessoa Física no DF .................................................58

Tabela 2 - Contribuintes do Distrito Federal por Regime de Tributação ...................59

Tabela 3 - Tetos Dde Concessão Para Crédito Urbano e Rural...............................66

Tabela 4 - Progressividade de Valores Concedidos na Área Urbana ......................67

Tabela 5 - Progressividade de Valores Concedidos na Área Rural...........................67

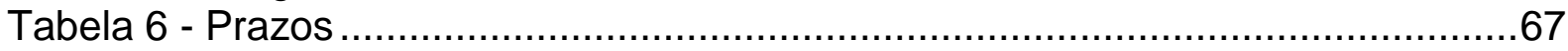

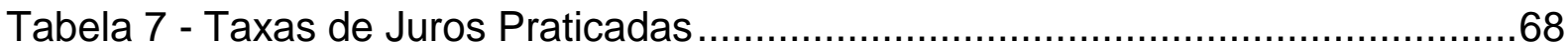

Tabela 8 - Evolução Da TJLP em 2016 ........................................................69

Tabela 9 - Volume de Concessões em 2001, 2006 a 2010 (R\$) ..........................76

Tabela 10 - Volume de Concessões em 2015 (R\$) ...............................................77

Tabela 11 - Categoria de Tomador por Registro em 2015 ...................................77

Tabela 12 - Classificação por Sexo em 2015 ...................................................77

Tabela 13 - Empregos Gerados/Mantidos em 2015 ............................................78

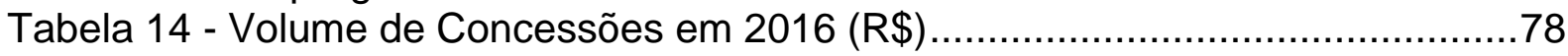

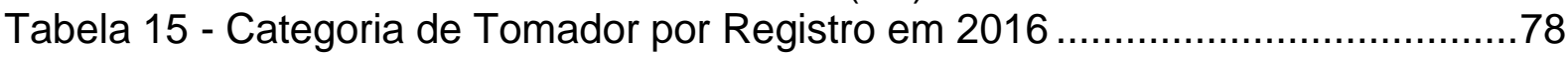

Tabela 16 - Classificação por Sexo em 2016 ……………………………….....79

Tabela 17 - Empregos Gerados/Mantidos em 2016 .............................................79 


\section{LISTA DE FIGURAS}

Figura 1 - A Estrutura das Microfinanças .....................................................24

Figura 2 - Distribuição do PIB no Distrito Federal em 2013 ................................56

Figura 3 - População Ocupada Segundo Setores de Atividades - 2014 .................57

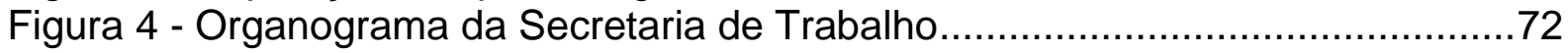

Figura 5 - Fluxograma do Processo de Concessão ………................................75 


\section{SUMÁRIO}

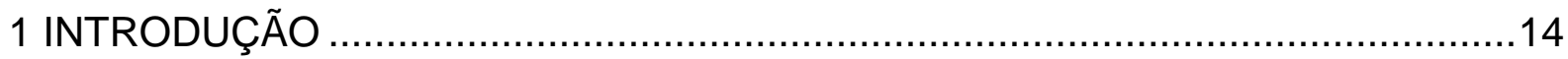



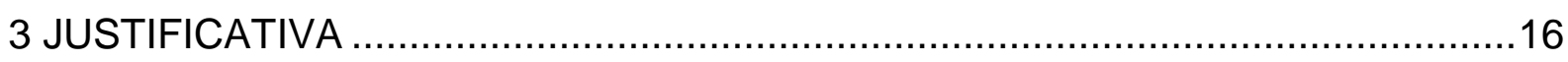



5 METODOLOGIA

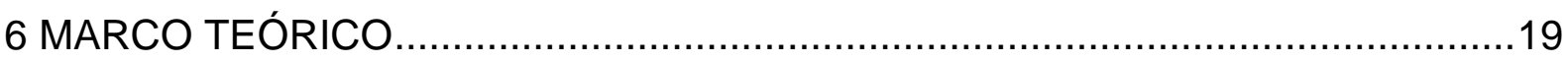

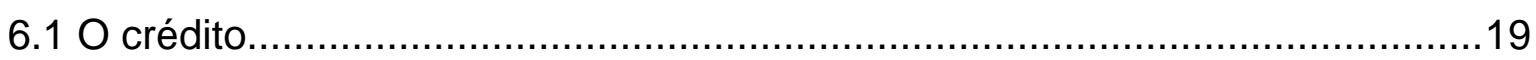



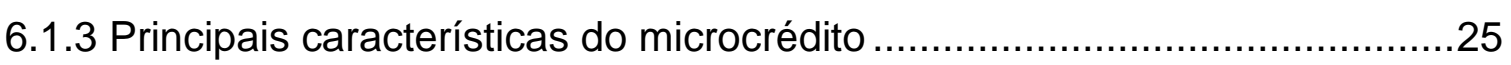

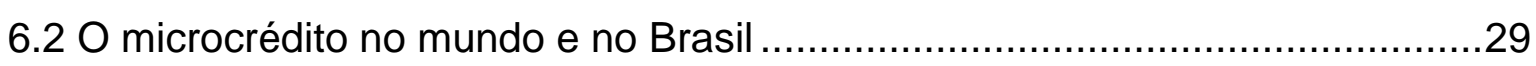



6.2.2 A experiência de microcrédito no Brasil...............................................33

6.2.3 Instituições expoentes de microcrédito no Brasil ....................................36

6.2.3.1 O Banco Nacional de Desenvolvimento Econômico e Social (BNDES) 37

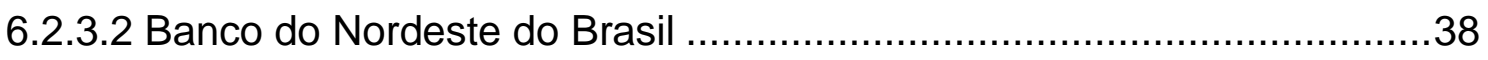



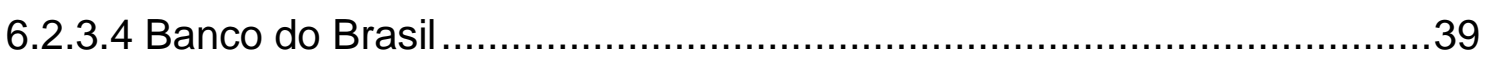

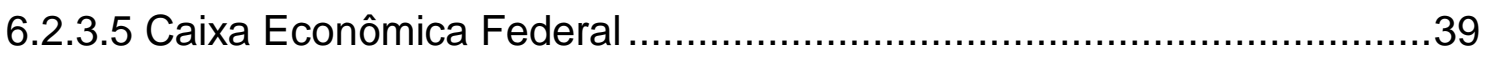

6.2.4 Os bancos privados e a oferta de microcrédito .......................................40

6.3 O microcrédito como política pública ……………..................................... 41

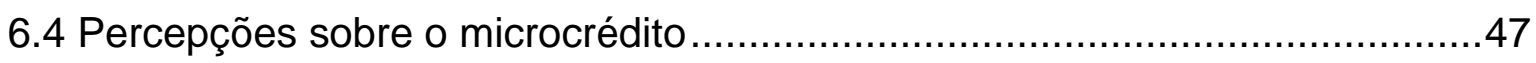



7 MICROCRÉDITO E EMPREENDEDORISMO NO DISTRITO FEDERAL...............55

7.1 Perfil das empresas e ocupações no Distrito Federal ...................................58

7.2 A oferta de microcrédito no Distrito Federal ..............................................59

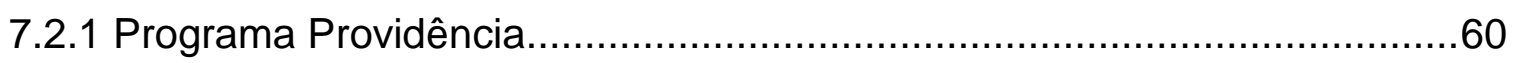



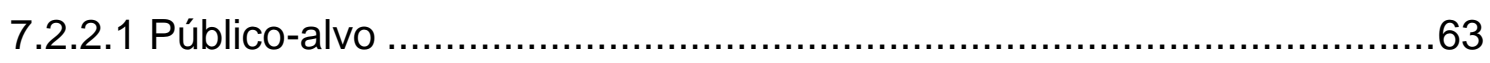


7.2.2.2 Destinatários especiais do microcrédito ..............................................64

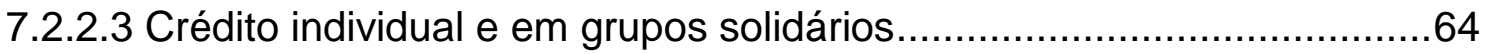



7.2.2.5 Limites de concessão, progressividade e taxas aplicadas ....................66

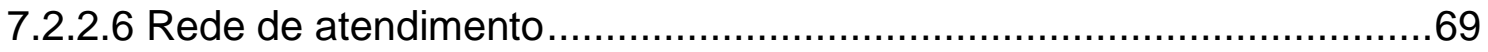

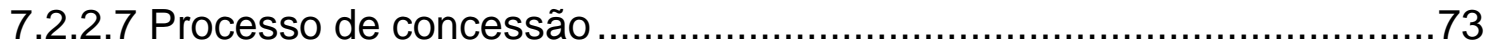

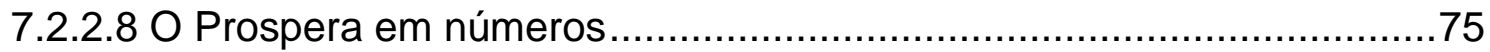

8 CONSIDERAÇÕES FINAIS E PERSPECTIVAS ............................................

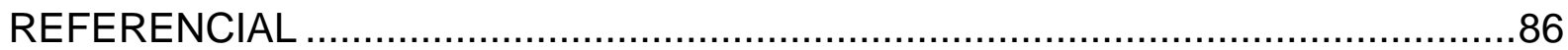




\section{INTRODUÇÃO}

Crédito trata-se de bem, serviço ou quantia em dinheiro postos à disposição mediante quaisquer tipos de provas (carnês, letras de câmbio, notas promissórias e outros) que configuram a oficialização de um compromisso de pagamento futuro.

Os custos de transação para a concessão de crédito fazem com que o sistema financeiro adote um comportamento conservador, excluindo determinados segmentos do acesso ao crédito, a exemplo, população de baixa renda, setor informal, micro e pequenas empresas, empresas nascentes, etc., além de privilegiar os financiamentos de curto prazo.

Essa exclusão ou restrição ao acesso ao crédito para alguns segmentos como população de baixa renda, microempreendimentos formais e informais, pequenas empresas etc ensejaram uma solução econômica e social, surgindo as microfinanças e o microcrédito.

Embora o conceito de microfinanças não seja algo novo, uma vez que há registros de crédito formal e instituições de poupança para pobres há décadas, Estrella (2008) defende que somente a partir de 1970 o microcrédito foi lançado no mundo todo a partir da inciativa do economista e banqueiro bengali Muhammad Yunus, com a fundação do Banco Grameen (O Banco do Povo), em Bangladesh, alavancou a ideia de que o empréstimo aos pobres era uma forma de valorizar aquele que está excluído por meio do incentivo ao empreendedorismo, tendo com isso, ganhado prêmio Nobel de economia.

No Brasil, as origens do microcrédito remontam a 1950, tendo sido um dos países pioneiros a implantar o microcrédito. Em 2005, surge o marco regulatório legal do microcrédito no Brasil com o Programa Nacional de Microcrédito Produtivo Orientado (PNMPO).

No Distrito Federal a iniciativa do microcrédito pode ser vista pela primeira vez em 1995 com a criação de um fundo público para atender os micro e pequenos empresários e empreendedores informais da cidade e do campo. Atualmente, 
mediante legislação específica existe o Programa Prospera de Microcrédito Produtivo e Orientado da Secretaria de Estado de Trabalho do Distrito Federal que contribui com o desenvolvimento do empreendedorismo na região por meio de concessões de crédito a taxas de juros baixas e procedimentos facilitados sob a supervisão de um agente de crédito que atua junto ao tomador orientando e contribuindo com seu desenvolvimento econômico e consequentemente da sociedade em geral. 


\section{OBJETIVO}

O objetivo geral deste trabalho é apresentar um estudo descritivo do microcrédito produtivo orientado no Distrito Federal, a partir do Programa Prospera do Governo do Distrito Federal, demonstrando sua interface com o empreendedorismo.

Os objetivos específicos são:

1. Estudar o microcrédito como um segmento das microfinanças;

2. Apresentar o histórico do microcrédito no Mundo e no Brasil

3. Apresentar exemplos de esforços de microcrédito no Brasil

4. Estudar o microcrédito enquanto política pública voltada às camadas mais carentes da sociedade

5. Apresentar resultados do Programa de Microcrédito do Governo do Distrito Federal e sua interface com o empreendedorismo do Distrito Federal

\section{JUSTIFICATIVA}

Apesar de o Brasil possuir um sistema financeiro bem desenvolvido, boa parte da população carente não tem acesso aos produtos e serviços financeiros, entre eles, é crédito produtivo, uma vez que a concessão de crédito historicamente não vai ao encontro dos grupos sociais de baixa renda e às regiões mais carentes.

Em geral, o sistema financeiro tradicional trabalha com uma série de exigências de forma a minimizar os riscos associados aos empréstimos, o que pode desencadear a exclusão de grande parte da população carente, entre estes, os empreendedores formais e informais de pequeno porte. Além disso, em função do custo oriundo da minimização dos riscos, as taxas de juros praticadas são elevadas, afastando ainda mais os tomadores que precisam.

Estudos demonstram que o Brasil está entre os países mais empreendedores do mundo, no entanto, a quase totalidade desses empreendedores não possui acesso ao crédito. Verifica-se que o sistema financeiro, em geral, não 
envida esforços no sentido de atuar com o segmento de micro e pequenas empresas e menos ainda com empreendedores informais. Tais segmentos são encarados como de alto risco pelos bancos convencionais, em função da percepção de que a instabilidade econômica dos mesmos prejudicaria sua capacidade de pagamento, somada à falta de garantias que esses empreendimentos formais ou informais podem oferecer.

Nesse contexto, o microcrédito produtivo orientado surge como possibilidade de acesso ao sistema financeiro, pois oferece oportunidade de crescimento através da concessão de pequenos créditos, com orientação e menores taxas de juros. Funcionando ainda como política pública para redução da pobreza, aumento da renda e estímulo ao empreendedorismo, promovendo o acesso das camadas mais carentes aos bancos.

A pretensão desse trabalho é colaborar com os estudos a respeito do microcrédito produtivo orientado no que se refere a sua aplicação no Distrito Federal, onde se registra sua existência desde 1995.

\section{PROBLEMA DA PESQUISA}

Evidencia-se que a política pública de microcrédito tem promovido o acesso ao crédito aos empreendedores menos favorecidos oportunidades de aumentar, diversificar e proteger suas fontes de renda.

Este trabalho foi realizado a partir estudo de caso da experiência de microcrédito produtivo orientado do Programa Prospera do Governo do Distrito Federal, tendo como hipótese a contribuição do Programa para o desenvolvimento das políticas de microcrédito no Distrito Federal em prol dos empreendedores ali instalados. 


\section{METODOLOGIA}

O trabalho é delineado como uma pesquisa empírica, adotando o método do estudo de caso, por permitir analisar uma organização real, colhendo, quando possível, em função da ausência ou dificuldade de acesso, informações a respeito do objeto de estudo, e cotejando com estudos teóricos existentes.

O enfoque do trabalho é descrição e análise da dinâmica do Programa de Microcrédito Produtivo e Orientado Prospera do Governo do Distrito Federal. 


\section{MARCO TEÓRICO}

\subsection{O Crédito}

Para Dicionário Eletrônico Michaelis (2016), o vocábulo português crédito tem a sua origem etimológica do latim creditum (particípio passado de credere: acreditar, confiar) assumindo o sentido comercial de "bem, serviço ou quantia em dinheiro postos à disposição de alguém por empresa, loja credora, estabelecimento bancário, financeira etc., mediante quaisquer tipos de provas (carnês, letras de câmbio, notas promissórias e outros) que configuram a oficialização de um compromisso de pagamento futuro"

Schrickel apud Araujo (2012) conceitua o crédito como todo ato de vontade ou disposição de alguém de destacar ou ceder, por determinado tempo, parte do seu patrimônio a um terceiro, considerando que essa parcela volte a sua posse integralmente, depois de decorrido o tempo estipulado.

Do ponto de vista econômico, o crédito é resultado da poupança feita por alguns, que transferem a outros, permitindo-lhes alcançar poder de compra atual e satisfazer suas necessidades de consumo. Para Silva apud Araujo (2012), existem agentes econômicos (famílias, empresas e governos) cujas rendas excedem seus consumos e investimentos, o que resulta em situação orçamentária de superávit, e por outro lado, outros agentes econômicos com situação orçamentária deficitária, necessitando de recursos para aproveitarem oportunidades de investimentos ou para financiarem consumo. Surge então a figura do intermediário financeiro que atua como receptor de recursos, deslocando-os para fontes produtivas.

Ainda que o conceito de crédito seja parte integrante do negócio em qualquer atividade empresarial, seja ela comercial ou industrial, na atividade bancária desenvolvida por intermediários financeiros ele constitui fator da maior importância, uma vez que constitui a essência do negócio dessas instituições. Para Silva apud Araujo (2012), "em um banco, o crédito é o elemento tradicional na relação com o cliente, isto é, é o próprio negócio" e define a ainda a concessão de 
crédito como a atividade de atividade de emprestar dinheiro, isto é, colocar à disposição do cliente determinado valor monetário em determinado momento, mediante promessa de pagamento futuro, tendo como retribuição por essa prestação de serviço, determinada taxa de juros cujo recebimento poderá ser antecipado, periódico ou mesmo ao final do período, juntamente com o principal emprestado.

Schrickel apud Araujo (2012) esclarece que em geral, a atividade de crédito está atrelada a um preço remuneratório pago pelo tomador do valor àquele que lhe emprestou, ao que chamamos de taxa de juros. A taxa de juros funciona como um elemento de compensação dos riscos assumidos pelo ente que empresta parte do seu patrimônio considerando que o mesmo poderá sofrer perdas ou desvalorização do patrimônio inicial. A esse risco, denomina-se risco de crédito e surge da possibilidade de as contrapartes não desejarem ou não serem capazes de honrar suas obrigações contratuais. Assim, o puro ato de emprestar uma quantia a alguém traz em si embutido o risco de crédito, uma vez que há a incerteza em relação à recuperação desse montante.

Afim de minimizar tais riscos, os credores estabelecem mecanismos de proteção adotados para evitar a inadimplência dos tomadores. Dentre os mecanismos de proteção existentes, Ribeiro e Carvalho (2006) destacam: a) monitoramento, por parte da instituição financeira, das operações de empréstimos, o que implica em custos de verificação; b) maior rigor contratual, com a exigência de que o tomador apresente garantias que possam ser executadas em caso de inadimplência; c) emprego de cláusulas contratuais protetoras e mecanismos restritivos. Esses mecanismos implicam em elevação dos custos de transação no mercado de crédito e a imputação de um caráter excludente a esse mercado, sendo que,

“...grande parcela dos pequenos e microempresários, formais e informais não consegue financiar seus empreendimentos economicamente viáveis por não possuir garantias reais aceitáveis, por não se adequar às exigências contratuais de monitoramento ou por demandar empréstimos muito pequenos, comparativamente aos custos de transação." (RIBEIRO; CARVALHO, 2006). 
Manos (2006) reforça que para garantir seus ganhos e até mesmo sua permanência num mercado baseado na confiança que os clientes depositam na instituição financeira, os agentes intermediários tendem a adotar uma postura conservadora no sentido da busca pelo contrato ótimo com exigências de garantias reais e com racionamento dos demandantes.

Braga e Toneto Júnior apud Manos (2006) concordam com essa ideia ao afirmando que os problemas da informação assimétrica e dos custos de transação fazem com que o sistema financeiro adote um comportamento conservador, excluindo determinados segmentos do acesso ao crédito, a exemplo, população de baixa renda, setor informal, micro e pequenas empresas, empresas nascentes, etc., além de privilegiar os financiamentos de curto prazo.

Como decorrência dessa exclusão Manos (2006) esclarece ainda que empreendimentos economicamente viáveis e que poderiam gerar emprego e elevar o nível de renda, podem ser excluídos do mercado de crédito e deixar de contribuir para o processo de crescimento econômico, o que gera um custo para a sociedade, uma vez que

\begin{abstract}
"Esclarecem ainda que o problema da exclusão é particularmente grave nos países em desenvolvimento, que caracterizam-se por uma grande participação do setor informal, das micro e pequena empresas e das populações de baixa renda. Assim, se o sistema financeiro não alcança estes segmentos, limita-se a alocação eficiente dos recursos, o investimento e a geração de emprego e renda. O mercado de crédito informal, com seus elevados custos, tende a assumir uma importância crucial para esses segmentos, penalizando-os em relação às empresas maiores e à população de alta renda, estimulando ainda mais a concentração de renda. (BRAGA e TONETO JR, 2000)
\end{abstract}

Identificada tal falha de mercado, Braga e Toneto Jr. (2000), defendem que a lacuna deixada pelas instituições financeiras privadas abre um espaço para atuação do setor público no mercado de crédito. Desta forma os governos 
estabelecem instituições de desenvolvimento direcionadas ao financiamento de longo prazo e daqueles empreendimentos que sofrem grande influência de fatores aleatórios, como no caso de pequenas ou novas empresas.

Nesse sentido, Braga e Toneto Jr. (2000) verificam ainda que tem surgido em uma série de países do Terceiro Mundo instituições de microcrédito que buscam, por meio de instrumentos alternativos, atender às necessidades de crédito dos segmentos excluídos do sistema financeiro tradicional, principalmente em relação às micro e pequena empresas, considerando o agravamento dos problemas de desemprego mundial e a importância deste segmento na geração de emprego.

\subsubsection{Microfinanças e Microcrédito}

Como visto anteriormente, a exclusão ou restrição ao de acesso a serviços creditícios e financeiros por parte de alguns segmentos como população de baixa renda, microempreendimentos formais e informais, pequenas empresas etc promoveram o surgimento de soluções alternativas. Entre estas soluções, temos as microfinanças e o microcrédito, apresentadas como ferramentas de inclusão social, destinadas às classes mais baixas.

Apesar de não haver consenso, Barone e Sader (2008), afirmam que microfinanças representam a oferta de serviços financeiros (crédito produtivo e para consumo, poupanças, seguros etc.) para a população de baixa renda que, normalmente, não possui acesso a esse tipo de serviços no sistema financeiro tradicional. Essa oferta pode ser realizada por agentes financeiros, strictu sensu como bancos, as Sociedades de Crédito ao Microempreendedor e à Empresa de Pequeno Porte (SCMs), e cooperativas ou não, como Organização Nãogovernamental (ONGs) e Organização da Sociedade Civil de Interesse Público (OSCIPS), conforme Simeon et al (2002).

Deangelo (2005), concorda que as microfinanças são representadas por serviços financeiros, voltados para a população mais carente que podem ser prestados por instituições autorizadas pelo governo e pelo BNDES, como toda e 
qualquer operação financeira destinada à população de baixa renda.

Simeon et al (2002) estabelece que microcrédito é "a concessão de empréstimos de relativamente pequeno valor, para atividade produtiva, no contexto das microfinanças".

Segundo o Programa Nacional de Microcrédito Produtivo Orientado PNMPO (Brasil, 2005), microcrédito é o "crédito concedido para o atendimento das necessidades financeiras de pessoas físicas e jurídicas empreendedoras de atividades produtivas de pequeno porte, utilizando metodologia baseada no relacionamento direto com os empreendedores no local onde é executada a atividade econômica"

Deangelo (2005), conceitua o microcrédito como "forma de empréstimo orientado, de pequeno porte, com metodologia própria, voltado para o desenvolvimento de atividade produtiva do setor formal e informal, visando gerar trabalho e renda".

Zouain e Barone (2007) estabelece que o "microcrédito é a concessão de empréstimos de pequeno valor a pequenos empreendedores informais e microempresas que não tem acesso ao sistema financeiro tradicional, sendo concedido mediante metodologia específica".

O microcrédito não é destinado a financiar o consumo, mas atuar como crédito produtivo, para financiamento de capital de giro e investimento fixo, sendo concedido com a participação de um agente de crédito, pessoa que assistirá o tomador antes, durante e depois da concessão, ainda conforme Zouain e Barone (2007).

É importante salientar que o microcrédito difere de outra modalidade de microfinanças, entendida como crédito popular, que embora seja destinada a população de baixa renda não estabelece vínculo com o aspecto produtivo sustentável, sendo destinado ao consumo ou pagamento de dívidas pessoais por exemplo. 
Barone e Sader (2008), estabelecem ainda diferenciação entre microcrédito e microcrédito produtivo orientado, sendo o primeiro definido como pequenos empréstimos à população muito pobre, para trabalhar por conta própria, permitindo gerar renda para seu sustento e de suas famílias, enquanto o segundo é um crédito produtivo popular, com foco no financiamento a microempreendedores de baixa renda, para aplicação em sua atividade profissional.

Santiago apud Matos et al (2014) apresenta ainda o conceito de surgimento de microcrédito orientado, como aquele em que a concessão está vinculada a capacitação gerencial dos tomadores como forma de promover o desenvolvimento sustentável.

Verifica-se uma convergência de conceitos em que o microcrédito produtivo orientado constitui um subconjunto do microcrédito, e ambos pertencem ao universo maior das microfinanças. Desta forma, podemos estruturar os serviços de microfinanças como apresento no gráfico a seguir.

Figura 1 - A Estrutura das Microfinanças
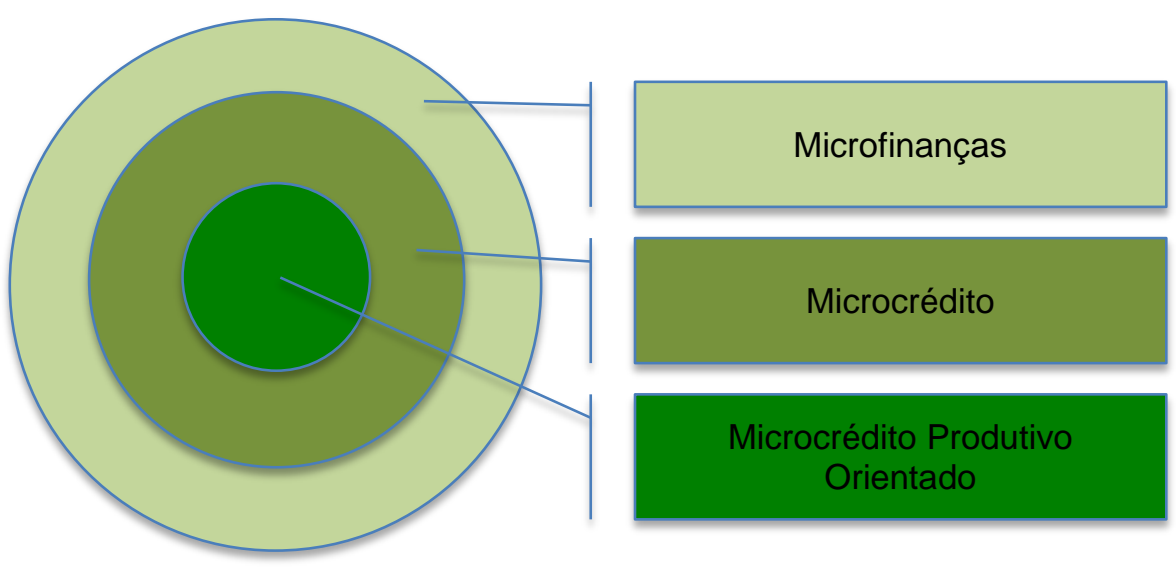

Fonte: Barone e Sader (2008)

O microcrédito tem sido visto como capaz de estimular a capacidade 
empreendedora dos seus beneficiários, bem como incentivador na busca pela autonomia dos mesmos, conforme defende Lima (2009), esclarecendo ainda que a concessão do microcrédito exige contrapartida dos tomadores em termos de ze comprometimento. As barreiras no acesso ao crédito pela população de baixa renda contribuem para sua exclusão financeira e social.

\subsubsection{Principais Características do Microcrédito}

O microcrédito goza de inúmeras peculiaridades próprias do seu contexto e metodologia de funcionamento, então faz-se importante apresentar as características do mesmo dentro do contexto das microfinanças.

Como visto anteriormente, vale salientar que outras modalidades de microfinanças (crédito para consumo, poupança, seguro, etc) existentes diferem do microcrédito por terem pouca relevância na repercussão social e efeito multiplicador, exigirem documentação formal extensa em um longo processo burocrático, prazos de vencimento longos, com maximização dos lucros pelo banco, e não terem finalidade pré-determinada, em geral sendo utilizadas para consumo ou pagamento de dívidas.

Assim, o microcrédito é uma modalidade de microfinanças voltada para o segmento da economia constituído por pequeno empreendimento informal e a microempresa. Isto é, seu objetivo é dar apoio aos negócios de pequeno porte, gerenciados por pessoas de baixa renda, não sendo destinado ao consumo.

Como verificado anteriormente a metodologia de concessão de crédito adotada pelas instituições financeiras tradicionais promove a exclusão do segmento de baixa renda do mercado de crédito bancário, pois em geral, tal segmento atua de maneira são informais, desprovido de registros contábeis organizados que permitiriam apresentar e analisar os diversos demonstrativos comuns às grandes empresas, como fluxo de caixa, balanço, demonstrativo de resultados entre outros. 
Barone et al (2002) afirmam que o microcrédito possibilita a concessão de crédito a empreendedores de baixa renda que não podem apresentar garantias reais, isto é, patrimônio próprio para assegurar o cumprimento da obrigação financeira contraída. Desta forma, o microcrédito, apresenta o aval solidário em que um grupo formado por 3 ou 5 empreendedores se reúnem afim de obter o crédito e assumem as responsabilidades solidariamente até que todo o empréstimo tenha sido quitado por todos.

\section{Verifica-se que}

"o aval solidário é uma das formas mais efetivas de colateral social. Nesse sistema, os tomadores de empréstimos formam grupos, no qual os membros se avalizam mutuamente. Dessa forma, os beneficiários fiscalizam uns aos outros para evitar a inadimplência e o cancelamento dos empréstimos". (LIMA, 2009). "A formação do grupo é autosseletiva, visando o conhecimento e o controle dos membros entre si” (ESTRELLA, 2008).

Yunus e Jolis (2000) advertem que o não cumprimento do pagamento semanal de uma parcela por qualquer dos membros prejudicaria todos os membros do grupo, impedindo acesso a novos créditos. Esta regra promovia o solidariedade entre os membros que se cotizam para ajudar o membro em dificuldades.

Colodeti (2011) afirma que a população pobre somente começou a ser vista como público consumidor de crédito principalmente através do aval solidário.

Segundo Lima (2009) o aval solidário não é adotado em todas as instituições de microcrédito, devido a fatores culturais, como a dificuldade dos tomadores em estabelecer laços de confiança entre si para a formação do grupo.

Para os empreendedores que não querem participar do aval solidário é possível apresentar um avalista/fiador que preencha as condições estabelecidas pela instituição de microcrédito, conforme esclarece Lima (2009).

Nesta situação, "os clientes fornecem em contrapartida algum tipo de colateral, seja ele o aval de vizinho, amigo ou parente, seja ele um bem patrimonial ou financeiro. Esse tipo de empréstimo se aproxima do sistema financeiro tradicional 
no tipo de exigência de colaterais" (ESTRELLA, 2008).

Ainda para Estrella (2008), outra característica importante do microcrédito é a figura do agente de crédito, que realiza o acompanhamento junto a cada cliente, afim de verificar a real necessidade de crédito do cliente e para o sucesso da operação financeira, atuando, em geral, como um orientador contábil-financeiro do empreendedor.

Para CEBDS - Conselho Empresarial Brasileiro para o Desenvolvimento Sustentável (2013), a figura do agente de crédito representa uma grande inovação, pois

"para muitas instituições financeiras, o agente de microcrédito é a grande inovação para o sucesso do mecanismo. Os agentes ou assessores de crédito gerenciam uma carteira de clientes, normalmente delimitada por áreas geográficas. Esses agentes coletam informações ativamente $e$ captam clientes para os bancos, tratando caso a caso, conforme as necessidades de cada empreendedor. $A$ ação do agente inclui a orientação no controle das contas, no orçamento doméstico, na renegociação de dívidas, na seleção de fornecedores, na organização das compras, etc. Também incentiva os empreendedores a pagar o INSS, explicando-Ihes a importância da formalização e da garantia future de aposentadoria e até oferece apoio moral para problemas de saúde familiars". (CEBDS, 2013)

E ainda

"é função do agente de crédito levar aos empreendedores as informações e orientações essenciais para o êxito do negócio, sendo o elo entre a instituição de microfinanças e o tomador de crédito. Essa ação passa pelo estabelecimento de uma relação de orientação profissional e de confiança para garantir o desenvolvimento do cliente e, conseqüentemente, o retorno dos empréstimos concedidos e a sustentabilidade da microfinanceira" (ESTRELLA, 2008)

Barone et al (2002) esclarecem que o atuação agente de crédito se inicia com uma entrevista com o pretendente ao microcrédito, no local do empreendimento, muitas vezes sua própria moradia, em que é relizado um diagnóstico da situação financeira e dos aspectos gerenciais do negócio, 
dimensionando a viabilidade do crédito a ser concedido. Diferente do crédito tradicional é a instituição que vai ao tomador, na figura do agente de crédito e não o contrário.

Outra característica marcante desta modalidade para Barone et al (2002) é a adequação do crédito ao ciclo de negócio que consiste em:

- Conceder empréstimos de valores pequenos: o empréstimo médio das instituições brasileiras de microcrédito está em torno de $R \$ 1.000,00$;

- Oferecer prazos de pagamentos curtos: semanais, quinzenais e, no máximo, mensais;

- Possibilitar a renovação dos empréstimos;

- Escalonar os empréstimos com valores crescentes, aumentando gradativamente até o limite estabelecido por cada instituição.

Com isso, Estrella (2008) defende que é criado um círculo virtuoso em que

"o tomador é incentivado a pagar em dia, já que esse é um indicativo importante para o recebimento de novo crédito, que pode ser de valor maior. O fato de o tomador de microcrédito vivenciar a obtenção, a administração e a liquidação de diversos créditos aumenta a confiança e a motivação em relação à possibilidade de crescimento do seu negócio e o grau de informação do seu pequeno empreendimento." (RODRIGUES apud ESTRELLA, 2008)

E por fim, outro aspecto importante que caracteriza o microcrédito é a taxa de juros,

"que deve ser sustentável, suficiente para cobrir os custos financeiros e administrativos da instituição concedente de crédito. Também pode ser subsidiada, ou seja, insuficiente para cobrir os custos financeiros e administrativos, e suportada por algum programa público de crédito". (ESTRELLA, 2008).

Por isso, Barone et al (2002) acreditam que o empreendedor de baixa renda busca reduzir ao máximo os custos de transação que, para ele, podem pesar mais do que o custo financeiro. Desta forma, a instituição de microcrédito deve buscar baixar os custos de transação da seguinte forma: a) estabelecer-se próxima da 
residência/local de trabalho dos clientes; b) minimizar a burocracia; c) agilizar a entrega do crédito. Os autores defendem que essas características incentivam o bom uso do crédito e o pagamento em dia, no entanto, pode aumentar os custos operacionais da instituição, levando a cobrança de juros maiores, se não houver eficiência administrativa.

Santiago apud Matos et al (2014), acrescenta ainda três traços relevantes do microcrédito, que

“...são raríssimos aqueles que direcionam empréstimos para microprodutores iniciantes.

$[\ldots]$

recomenda que os tomadores de financiamentos sejam considerados clientes, e não "pedidores" de dinheiro a fundo perdido.

[...]

As diversas instituições que fomentam o crédito popular assumem o atendimento preferencial ao gênero feminino, pelo fato de as mulheres responderem, de modo mais efetivo, pelos ganhos sociais do microcrédito, destinando-os para as suas famílias;" (SANTIAGO apud MATOS et al, 2014)

\subsection{O Microcrédito no Mundo e no Brasil}

\subsubsection{Antecedentes Mundiais}

Para Estrella (2008), o conceito de microfinanças não é propriamente novidade, pois grupos de poupadores e de crédito existem há séculos em países como Ghana, México, Indonésia, Sri Lanka e Bolívia. Há registro de crédito formal e instituições de poupança para pobres há décadas, provendo uma alternativa para clientes tradicionalmente negligenciados pelo sistema financeiro tradicional, através de cooperativas e instituições financeiras de desenvolvimento.

E embora Estrella (2008) apresente que Jonathan Swift foi um dos precursores do microcrédito no início do século XVIII, pois realizava pequenos 
empréstimos, por curto prazo de tempo, para a população rural da Irlanda, foi somente a partir de 1970, que o microcrédito tomou notoriedade internacional, com Muhammad Yunus, economista e banqueiro bengali, com a fundação do Banco Grameen (O Banco do Povo), em Bangladesh, conforme Colodetti (2011).

Yunus, inconformado com a situação de pobreza que o cercava, desenvolveu o modelo de microcrédito afim de oportunizar crédito às pessoas mais pobres do bairro de Jobra:

"Em 1976, quando catedrático do Programa de Economia Rural da Universidade de Chittagong, Yunus, insatisfeito pelo fato de a Economia manter-se distante dos problemas da vida real, em especial da pobreza que assolava o mundo, emprestou 27 (vinte e sete) dólares de seu próprio bolso para 42 (quarenta e duas) mulheres da aldeia de Jobra, próxima à Universidade. $O$ intuito do professor foi permitir a estas mulheres a aquisição de matéria-prima para confeccionarem seus artesanatos, de modo a livrá-las das garras de agiotas que as mantinham em regime de trabalho análogo à escravidão (ESTIGARA, 2008).

Somado a isso, a parcela pobre da população sofria uma série de preconceitos como estabelecem Yunus e Jolis (2000):

a)os pobres devem ter alguma formação antes de empreender uma atividade geradora de rendas;

b) o crédito, por si só, não serve para nada; deve ser acompanhado de projetos de formação, de marketing, de transporte, de tecnologia e de educação;

c) os pobres não sabem economizar;

d) os pobres não sabem trabalhar em equipe;

[...]

i) os pobres preferem trabalhar para um patrão a se ocupar de seu destino;

j) é possível que o crédito desafogue os pobres temporariamente, mas não terá nenhum efeito a longo prazo, nada fará para promover uma reestruturação equitativa da sociedade (YUNUS e JOLIS, 2000).

Desta forma, para Muhammad Yunus é, com frequência, citado na bibliografia como responsável pelo modelo de microcrédito operacionalizado 
atualmente em todo o mundo conforme Barone (2007), Estrella (2008) e Estigara (2011).

Para a surpresa do economista, Yunus apud Estigara (2008), "todos esses empréstimos foram pagos pontualmente, conferindo-lhe a ideia de que esse processo talvez pudesse ser multiplicado indefinidamente, como meio para proporcionar a libertação da pobreza". Desde então, esse tipo de operação foi expandido para vilarejos vizinhos, obtendo o apoio do Banco Central de Bangladesh e outros bancos comerciais, até a criação do Banco Grameen em 1983 para o qual foram utilizados financiamentos e doações diversas.

Yunus tinha como premissa que o empréstimo para empreendedoras mulheres seria útil para todo o grupo familiar envolvido, e por isso, priorizava o empréstimo para as mulheres, dentro do segmento social dos mais pobres, como forma de empoderar tais tomadores em prol da melhoria da situação social de todos, conforme se verifica em Yunus e Jolis (2010).

O modelo desenvolvido por Grameen utilizava um sistema de pagamento semanal, com parcelas reduzidas, e um aval concedido por um grupo de cinco pessoas com o mesmo status socioeconômico, denominado aval solidário. Os empréstimos são concedidos de forma sequencial: primeiro, para dois membros do grupo, que ao pagarem em dia, permitem que sejam concedido crédito a outros dois grupos, que cumprindo o pagamento, abrem a concessão aos últimos dois membros envolvidos, isto em intervalos de 6 semanas.

Segundo Estigara (2008), o Banco Grameen tem como características:

- empréstimos por um ano;

- prestações semanais de um montante fixo;

- pagamento uma semana depois do recebimento do dinheiro;

- taxa anual de juros de $20 \%$;

- a cada semana pagam-se $2 \%$ da soma emprestada, durante 50 semanas;

- os juros representam a soma de duas takas (moeda bangladesa) por semana para um empréstimo de 1.000 takas 
O sucesso do Banco do Povo bangladês se traduz pelo crescente volume de empréstimos concedidos a cada ano e pelas reduzidas taxas de inadimplência, conforme pode ser visualizado a partir das tabelas a seguir.

Braga e Toneto Jr (2000) identificaram no período de quase duas décadas, uma trajetória nitidamente crescente no volume de empréstimos concedidos e número de pessoas beneficiadas, índices de inadimplência próximo de zero em quase todo o período.

O grande sucesso desta instituição está exatamente no tipo de arranjo contratual, de grupos solidários, como premissa em suas operações de crédito e que busca reduzir o custo de seleção e monitoração do empréstimo, além de criar incentivos ao pagamento do mesmo, contribuindo assim para reduzir o risco de inadimplência das operações.

A importância do Banco Grameen se dá ao fato de que desde 1950 já haviam tentado fornecer crédito para os pobres, no entanto, as tentativa não foram adiante, principalmente em função da ineficiência, corrupção, custos crescentes nos subsídios, favorecimentos indevidos, ocasionando o racionamento do crédito, conforme esclarece Neri et al (2008). Em 2006, Muhammad Yunus e o Banco Grameen receberam o Prêmio Nobel da Paz por suas realizações na área do microcrédito conforme Nobel Foundation (2006).

A Organização das Nações Unidas (ONU) organizou em Washington/EUA, em fevereiro de 1997, o The Microcredit Summit que foi o mais importante evento até então realizado em escala mundial sobre a questão da disponibilização do microcrédito às populações carentes com a finalidade de desenvolver atividades produtivas para a geração de renda. $O$ evento estabeleceu a meta de iniciar um movimento mundial para disponibilizar o microcrédito ao alcance de 100 milhões de pessoas, especialmente para as mulheres, até o ano de 2005.

Colodeti (2011) verifica que na América Latina e no Caribe, a instituição que de microcrédito Acción Internacional oferece desde 1970 serviços de gestão e 
assistência técnica, apoiando a implementação de instituições de microcrédito em diversos países como Argentina, Brasil, Bolívia, Guatemala, Colômbia, República Dominicana, Equador, Haiti, Honduras, Panamá, Paraguai, Venezuela, México, Peru, El Salvador e Nicarágua .

\subsubsection{A Experiência de Microcrédito no Brasil.}

No Brasil, segundo Zouain e Barone (2007), as origens do microcrédito podem ser remontadas ao final da década de 1950, no Rio de Janeiro, cidade em que o Dom Helder Câmara, desenvolveu uma "carteira de empréstimos" com a finalidade de auxiliar os marginalizados da sociedade a empreenderem em alguma atividade produtiva. Tal ação apresentava-se como uma alternativa proposta pela Igreja Católica para enfrentar a miséria e contribuir com o desenvolvimento humano, que depois viria a ser denominado Banco da Providência.

Para Barone et al (2002), o Brasil foi um dos pioneiros no mundo a implantar iniciativas de microcrédito para o setor informal urbano, quando em 1973, nas cidades de Recife e Salvado, foi implantada União Nordestina de Assistência a Pesquenas Organizações (UNO). Realizada por iniciativa da organização nãogovernamental Accion Internacional, com ajuda de empresas e bancos locais, tinha por objetivo conceder microcréditos bem como capacitar trabalhadores de baixa renda, formando-os em temas como gerenciamento básico, promovendo o caráter associativo, colaborativo e cooperativo entre as populações de baixa renda assistidas pelo programa.

Ainda segundo Barone et al (2002), a partir da iniciativa da UNO, a metodologia de grupos solidários, com concessões de crédito mútuo forma replicadas pelo Brasil, sendo que em 1987 surgiu o Centro de Apoio aos Pequenos Empreendimentos Ana Terra (CEAPE/RS), que contou com o o apoio do Banco Interamericano de Desenvolvimento (BID) e da Inter-American Foundation (IAF) para a composição inicial de funding (recursos para empréstimos) utilizando a metodologia de microcrédito produtivo orientado, visando a sustentabilidade dos empreendedores excluídos do sistema financeiro tradicional. 
Ainda na década de 1980, segundo Zouain e Barone (2007), surgiu no Brasil uma modalidade de microcrédito voltada exclusivamente para as mulheres, denominada Banco da Mulher (Associação Brasileira para o Desenvolvimento da Mulher). Realizada com apoio do UNICEF e do BID, utilizava metodologia de grupos solidários. Posteriormente, a instituição passou a incluir homens entre seus beneficiários.

Segundo os mesmos autores, embora a iniciativa da sociedade civil tenha sido a responsável pela introdução do microcrédito no Brasil, o ambiente de inflação elevada na década de 1980 e início da década de 1990 inviabilizou o surgimento e o desenvolvimento de uma quantidade significativa de experiências. No entanto, a partir da estabilização econômica, alcançada em meados da década de 1990, formou-se um ambiente favorável poucas instituições que operavam microcrédito, podendo expandir suas carteiras de crédito.

Silva (2007) considera que a segunda metade da década de 90 é marcada por uma grande expansão dos programas de microcrédito no país com a atuação do poder público dos três níveis de governo em políticas e programas de microcrédito, com ações governamentais em nível federal e em nível subnacional. As ações do poder público relatadas são de três tipos: a) ações regulatórias, que se referem às alterações na regulação da atividade; b) ações em primeiro piso, caracterizadas pela operação direta da concessão de crédito; e c) ações de segundo piso, caracterizadas pelo suporte às operações de primeiro piso com apoio técnico ou financeiro

A partir de 1994, o governo federal se mobilizou em torno de políticas estruturais diretas voltadas para a geração de emprego e renda procurando como estratégia diminuir o desemprego, evitar a instabilidade e a exclusão social, promovendo o desenvolvimento econômico, programas que se caracterizassem como sociais, não-assistencialistas e de dimensão econômica, facilitando o acesso ao crédito por meio de ações basicamente na ponta da oferta de recursos financeiros. Assim, surgia o Programa de Geração de Emprego e Renda (PROGER), com recursos provenientes do Fundo de Amparo ao Trabalhador (FAT), coordenados pelo Ministério do Trabalho e Emprego (MTE), que tinha por objetivo 
conceder crédito a setores da sociedade com pouco ou nenhum acesso ao sistema financeiro tradicional, associado a ações de capacitação e assistência técnica;

Colodeti (2011) afirma que em 1995, durante o Governo de Fernando Henrique Cardoso, o Conselho da Comunidade Solidária, juntamente com o Instituto de Pesquisa Econômica Aplicada (IPEA) e o governo do Distrito Federal, identificaram que os programas de microcrédito deveriam ser incentivados e expandidos, desenvolvendo o Programa de Crédito Produtivo Popular (PCPP) e o Programa de Desenvolvimento Institucional (PDI), com o intuito de construir as bases de sustentação e expansão do microcrédito no País. Tais iniciativas que tiveram forte adesão no âmbito da sociedade civil e da iniciativa privada em vistas à redução da pobreza.

Em 2005, durante o Governo de Luís Inácio Lula da Silva, foi estabelecido o marco regulatório legal do microcrédito no Brasil, a partir da aprovação da Lei 11.110, de 25 de abril de 2005 que estabelecia o Programa Nacional de Microcrédito Produtivo Orientado (PNMPO), coordenado pelo Ministério do Trabalho e Emprego (MTE), substituindo o PCPP estabelecido anteriormente, conforme Colodeti (2011).

A Lei 11.110, de 25 de abril de 2005 estabelecia o Microcrédito Produtivo Orientado como:

O Crédito concedido para o atendimento das necessidades financeiras de pessoas físicas e jurídicas empreendedoras de atividades produtivas de pequeno porte, utilizando metodologia baseada no relacionamento direto com os empreendedores no local onde é executada a atividade econômica (BRASIL, 2005).

O Programa Nacional de Microcrédito Produtivo Orientado (PNMPO), tem por objetivos gerais:

- Incentivar a geração de trabalho e renda entre os microempreendedores populares;

- Disponibilizar recursos para o microcrédito produtivo orientado; 
- Oferecer apoio técnico às instituições de microcrédito produtivo orientado, com vistas ao fortalecimento institucional destas para a prestação de serviços aos empreendedores populares.

As principais fontes de recursos para o PNMPO são oriundas do Fundo de Amparo ao Trabalhador (FAT) e são alocados em bancos públicos federais, podendo ser repassados às diversas instituições de Microcrédito produtivo orientado - IMPO's, Organizações da Sociedade Civil de Interesse Social (OSCIPS), Cooperativas de crédito, Sociedades de Crédito ao Microempreendedor (SCMs). Cabendo ainda ao PNMPO a função de fomentar o microcrédito, principalmente através da promoção de seminários anuais, onde são feitas palestras, oficinas, discussão de gargalos e desafios do microcrédito no país, conforme se verifica em Ministério do Trabalho e Emprego/MTE (2016).

O PNMPO, desde a sua criação até o final de 2013, teve adesão em torno de 480 instituições de microcrédito. Até 2010, houve repasses do FAT para esse programa da ordem de $\mathrm{R} \$ 24$ milhões. (BRASIL, 2011). Em junho de 2012, havia cerca de 1,5 milhões de clientes de microcrédito ativos no programa, totalizando um volume de microcrédito concedido da ordem de $\mathrm{R} \$ 2,46$ bilhões. (BRASIL, 2012).

Conforme verificação atual, o sítio eletrônico do Ministério do Trabalho e Emprego/MTE (2016) disponibiliza a lista de instituições de microcrédito produtivo orientado que atuam no território nacional, somando quase 500 instituições entres agências de fomento, Organizações da Sociedade Civil da Interesse Social (OSCIPs), cooperativas de crédito e Sociedades de Crédito ao Microempreendedor (SCMs).

\subsubsection{Instituições Expoentes de Microcrédito no Brasil}

Apresentamos a seguir instituições de microcrédito que atuam no Brasil de maneira significativa entre instituições de caráter público nacional e subnacional e ainda instituições privadas. 
Considerando o Programa Nacional de Microcrédito Produtivo Orientado (PNMPO) segundo os 8 anos de atuação, cerca de 14 milhões de microempreendedores tiveram acesso ao microcrédito produtivo orientado, com $R \$$ 24 bilhões concedidos em crédito

Os recursos do PNMPO são em geral destinados aos bancos públicos federais que são hoje os responsáveis pela maior parte das operações do mercado de microcrédito, em sua maioria dentro do programa Crescer. Das 3,5 milhões de pessoas que já tomaram um empréstimo no Crescer, 1,2 milhão delas recebe o Bolsa Família, 76\% dos empréstimos do Crescer foram para o Nordeste e $64 \%$ dos beneficiados em todos o País, são mulheres.

Em dois anos e meio do programa, 2,5 bilhões de reais foram concedidos em empréstimo no programa Crescer, oferecido até o momento por instituições públicas federais e estaduais. Participam do programa o Banco do Nordeste, a Caixa Econômica Federal, o Banco do Brasil, o Banco da Amazônia, o Banrisul, o Banestes e a Agência de Fomento do Paraná (BRASIL, 2015).

\subsubsection{O Banco Nacional de Desenvolvimento Econômico e Social (BNDES)}

O Banco Nacional de Desenvolvimento Econômico e Social (BNDES) é a principal fonte de recursos para o microcrédito no Brasil. A atuação do BNDES na área do microcrédito teve seu início em 1996, com o Programa de Crédito Produtivo Popular, que provia fundos para as instituições de microcrédito. Em 1997, o BNDES firmou um Convênio de Cooperação Técnica com o Banco Interamericano de Desenvolvimento (BID), obtendo recursos não reembolsáveis com os quais desenvolveu um programa visando a fortalecer institucionalmente o segmento de microcrédito. A opção por uma abordagem empresaria refletia-se no destaque da auto-sustentabilidade das instituições de microcrédito como objetivo, como se depreende das palavras de Francisco Gros, então presidente da instituição

Segundo Rosas (2010), o BNDES criou o Programa BNDES Microcrédito, com nova simplificação dos procedimentos internos e aumento dos recursos 
destinados ao microcrédito a partir de 2010. O novo programa incluiu o aumento do valor mínimo de financiamento às instituições repassadoras, o aumento do prazo de carência de dois anos para três anos e a simplificação dos procedimentos para a liberação dos .

Rocha (2013) indica que entre 2005 e 2012, o valor desembolsado pelo microcrédito do BNDES era de 308 milhões. Em 2012, 142 milhões de reais foram desembolsados no programa, e de janeiro a outubro de 2013 os valores liberados chegaram a 127 milhões de reais.

\subsubsection{Banco do Nordeste do Brasil}

O Banco do Nordeste do Brasil (BNB) é um banco múltiplo, com sede em Fortaleza, Ceará. O BNB iniciou suas atividades de microcrédito de 1997, com cinco unidades piloto. Com o apoio do Banco Mundial e da organização não governamental Acción International, lançou seu programa de microcrédito - o Crediamigo - em 1998 conforme SOUZA (2011). O crescimento da cobertura geográfica e do número de clientes foi acelerado, levando o Crediamigo a tornar-se o maior programa de microcrédito do país, com uma carteira ativa de 2,1 bilhões e mais de 8 bilhões de reais concedidos.

O programa tem recebido o reconhecimento internacional. Em 2008, o programa Crediamigo recebeu o prêmio Excelência em Microfinanças, concedido pelo Banco Americano de Desenvolvimento (BID). Atua ainda com linha de crédito rural e capacitação empreendedora e ambiental.

\subsubsection{Banco da Amazônia}

O Banco da Amazônia iniciou seu programa de microcrédito - o Amazônia Florescer - em 2007. O Banco da Amazônia utiliza a metodologia de aval solidário, e atingiu em 2013 uma carteira de 24,1 mil clientes ativos conforme Banco da Amazônia (2016). 
Em 2013, o Amazônia Florescer apresentou crescimento de 71\% e 92\%, respectivamente, no quantitativo de clientes financiados e na aplicação de recursos, em razão das metas estabelecidas pelo Programa Crescer. Até 2013, o programa Amazônia Florescer havia concedido mais de 117,2 milhões de reais a 86.599 empreendedores e aplicado mais de 117 milhões de reais Banco da Amazônia (2016).

\subsubsection{Banco do Brasil}

O Banco do Brasil iniciou as atividades de microcrédito produtivo orientado em setembro de 2011, no âmbito do Programa Crescer conforme Apemec (2016).

O Banco do Brasil não exige garantias para pessoas físicas. Desde o início de sua atuação, o banco concedeu 1,9 bilhão de reais em 1,3 milhão de operações contratadas, atendendo mais de um milhão de clientes em dois anos. Já foram atendidos mais de 1 milhão de clientes em dois anos. De janeiro a outubro de 2013, o volume foi de $R \$ 1,01$ bilhão ou $162,5 \%$ acima do registrado no mesmo período de 2012, ano em que a concessão de empréstimos nessa modalidade superou 763 milhões de reais segundo Apemec (2016).

\subsubsection{Caixa Econômica Federal}

A Caixa Econômica Federal começou a trabalhar com microcrédito no ano de 2001. Com o início do programa Crescer, a Caixa criou a empresa Caixa Crescer, com novecentos agentes de microcrédito. A partir do Programa Crescer, os números avançaram: de dezembro de 2011 até janeiro de 2013, foram feitos 743 mil contratos de microcrédito, no valor de $\mathrm{R} \$ 1,6$ bilhão. Segundo Eugênia Regina de Melo, superintendente nacional da Caixa Econômica Federal, 14\% dos contratos de microcrédito têm como clientes os beneficiários do programa Bolsa Família (EBC, 2016). 


\subsubsection{Os Bancos Privados e a Oferta de Microcrédito}

Embora a lei 10.735, de 11 de setembro de 2003, estabelece a aplicação de recursos correspondentes a $2 \%$ dos depósitos à vista captados pelos bancos comerciais exclusivamente em operações de microcrédito, verifica-se que tais instituições não operam o microcrédito como os organismos públicos ou sem fins lucrativos.

Para Pimentel e Kerstenetzky (2008), a dificuldade de acesso às informações sobre o comportamento financeiro da população de baixa renda e a falta de garantias, dificultam a atuação de bancos privados com o microcrédito. Os autores entendem que por algum motivo, o microcrédito não é visto como um bom negócio por parte dos bancos comerciais - a despeito do modelo e das atraentes taxas de juros e de inadimplência.

Também Carvalho (2016) compartilha de opinião parecida em relação ao insucesso do microcrédito nas instituições bancarias privadas quando diz que

"A inadimplência é realmente reduzida no microcrédito, mas o retorno da oferta de crédito em si é baixo, e não é uma operação que cria clientela para outros serviços oferecidos pelos bancos (como aplicações em Fundos, por exemplo, ou gestão de serviços como folhas de pagamento, etc). Além disso, custos operacionais devem ser elevados, pela necessidade maior de atendimento físico do cliente. Do mesmo modo, os mais pobres não têm contas em bancos não porque se exijam muitos documentos, mas porque aos bancos não interessa depósitos de pequeno valor." (CARVALHO, 2016)

Em 2014 o Banco Bradesco juntamente com o Banco do Brasil criou uma empresa para foi desenvolvida para orientar, prospectar e acompanhar microempreendedores na tomada de linhas específicas de crédito. A companhia nasce com uma carteira de $\mathrm{R} \$ 70$ milhões e um projeto piloto de cerca de 60 mil contratos. O foco do banco seriam negócios bem pequenos, que seriam estimulados a crescerem mediante orientação sobre a tomada de crédito, conforme Bronzati (2016). 


\subsection{O Microcrédito como Política Pública}

O microcrédito deve ser analisado não somente sob a ótica econômica, mas também como uma política pública, uma vez que é tradicionalmente considerado uma política de desenvolvimento econômico e social local, útil para a superação da pobreza e para a geração de emprego e renda. Sendo assim, é importante salientar alguns aspectos para a compreensão do microcrédito como uma ação de intervenção do Estado visando o desenvolvimento social a partir do mercado financeiro.

Souza (2007) afirma vários fatores contribuíram para o avanço do campo de conhecimento denominado políticas públicas: adoção por diversos países de políticas restritivas de gasto, adoção de orçamentos equilibrados entre despesas e receitas, restrição à intervenção do Estado, além da dificuldade, principalmente em países em desenvolvimento, em especial da América Latina de desenvolver políticas públicas que impulsionassem o desenvolvimento e inclusão social.

Embora os estudos sobre políticas públicas tenham sido iniciados em meados da década de 1950, no Estados Unidos, Souza (2007), demonstra que os "pais fundadores" da área de políticas públicas não estabeleceram definição de política pública que possa ser declarada como única e melhor, assim, apresenta a política pública como "o campo do conhecimento que busca, ao mesmo tempo, colocar o governo em ação elou analisar essa ação (variável independente) e quando necessário propor mudanças no rumo ou curso dessas ações (variável dependente)" (SOUZA, 2007, p26).

Peters apud Souza (2007) esclarece que a política pública é tida como o somatório das atividades dos governos, que podem agir diretamente ou por meio de delegação, influenciando a vida dos cidadãos.

Saravia (2007) esclarece ainda que a política pública "está orientada a manter o equilíbrio social ou a introduzir desequilíbrios destinados a modificar essa realidade". Portanto, as políticas públicas podem ser refletidas em ações ou ainda omissões propositais do Estado no sentido de prevenir, corrigir, manter ou modificar 
determinada situação social mediante planejamento.

Por fim, enfatiza-se que

"as políticas públicas são ações governamentais dirigidas a resolver determinadas necessidades públicas. As políticas podem ser sociais (saúde, assistência, habitação, educação, emprego, renda ou previdência), macroeconômicas (fiscal, monetária, cambial, industrial) ou outras (cientifica e tecnológica, cultural, agrícola, agrária)" (GELINSKI e SEIBEL apud MIGUEL, 2012).

Desta forma, o microcrédito é abordado não como tema exclusivamente econômico, mas como um programa governamental que representa um projeto de caráter social implantado via mercado financeiro.

Como o acesso ao mercado de serviços financeiros formais é praticamente vedado aos mais pobres e às empresas pequenas, criando uma espiral de retroalimentação negativa que dificulta ou simplesmente os exclui desse mercado, o que para Matos et al (2014) por sua vez, distorce o funcionamento do setor de serviços financeiros, formando as estruturas concentradoras de mercados que permanecem em equilíbrio com menor volume de operações e taxas de juros mais elevadas do que seriam caso os mercados fossem mais competitivos.

Para Carruthers apud Miguel (2012), um mercado financeiro está repleto de processos sociais, que envolvem incertezas e vulnerabilidade, o que leva a questão sobre o que causa a confiança e quais as suas consequências. Por isso, o crédito se tornou uma parte essencial das economias modernas, em que o problema da confiança se tornou presente. Pois sem alguns mecanismos como instituições e constrangimentos sociais que gerem confiança o crédito se torna inviável e o sistema financeiro de um país pode deixar de funcionar.

A partir desta perspectiva, verifica-se que as políticas públicas que têm por intuito de favorecer o acesso ao microcrédito vêm contribuindo também para a constituição de um mercado de microfinanças, principalmente no aspecto institucional com a criação de uma política especifica voltada para este setor. 
Com isso, a concessão de crédito a população de baixa renda através do microcrédito tem sido realizada em diversos países do mundo com forma de combater a pobreza. Boa parte da população atendida não se encontra apenas sem uma alternativa de renda, mas excluída dos serviços do sistema bancário tradicional, principalmente sem acesso a empréstimos para fomentação de atividades econômicas.

As ações governamentais que estão orientadas à geração de emprego e renda têm sido utilizadas sistematicamente para combater a pobreza, o desemprego e os baixos níveis de rendimentos de vários segmentos do mercado de trabalho.

Silva (2007) considera que a entrada do poder público no espaço da microfinanças tem favorecido o desenvolvimento desse setor, assegurando assim, certa sustentabilidade ao mesmo, e a criação PNMPO ratifica o reconhecimento do microcrédito como política pública voltada para o desenvolvimento socioeconômico, bem como demonstra o poder público como o principal fomentador do setor de microfinanças no país.

Já havia há um tempo a preocupação das autoridades brasileiras com o financiamento de setores que seriam naturalmente excluídos do sistema financeiro tradicional quer pelo elevado risco quer pelo elevado custo de transação. A forma assumida pelas políticas que visavam eliminar este problema era a criação de entidades financeiras, ou linhas de crédito específicas para determinados segmentos (agricultura, pequena e micro empresa," etc.) ou o direcionamento dos recursos bancários (basicamente depósitos vista). Estas políticas acabavam se traduzindo em subsidios ou programas de renegociações de divida com grande ônus para o poder público. No entanto, a instabilidade econômica vivida nas últimas décadas e a ausência de políticas desenvolvimentistas levaram as instituições financeiras públicas a adotarem na maior parte dos casos critérios de eficiência privados para a definição de suas políticas operacionais.

Saravia (2007) estabelece características comuns às políticas públicas quais sejam: 
“a) institucional: a política é elaborada ou decidida por autoridade formal legalmente constituída no âmbito da sua competência e é coletivamente vinculante;

b) decisório: a política é um conjuntoseqüência de decisões, relativo à escolha de fins e/ou meios, de longo ou curto alcance, numa situação específica e como resposta a problemas e necessidades;

c) comportamental, implica ação ou inação, fazer ou não fazer nada; mas uma política é, acima de tudo, um curso de ação e não apenas uma decisão singular;

d) causal: são os produtos de ações que têm efeitos no sistema político e social" (SARAVIA, 2007)

Thoenig apud Saravia (2007) enfatiza que há cinco elementos que podem caracterizar uma política pública: a) um conjunto de medidas concretas; b) as decisões sobre alocação de recursos; c) inserção em um quadro geral de ações; d) definição de público-alvo; e) definição de metas e objetivos. É interessante notar que apesar da definição de objetivos e metas, de antemão não se costuma definir finalidades precípuas para as políticas públicas, senão que as mesmas devem atender os interesses da sociedade.

É possível verificar que os programas de microcrédito estão incluídas no entre as políticas de geração de emprego e renda que para Barros et al apud Miguel (2011), podem ser organizadas em grandes conjuntos:

a) Políticas compensatórias têm como objetivo transferir renda a um conjunto de trabalhadores desempregados ou de baixa renda, eventualmente com a exigência de alguma forma de contrapartida. Como exemplos há: o Seguro Desemprego, o Abono Salarial, o Fundo de Garantia por Tempo de Serviço (FGTS) e as frentes de trabalho;

b) Políticas distributivas que procuram influenciar diretamente o salário os trabalhadores ocupados por meio de legislação específica, que exercem um controle direto sobre os mínimos salariais ou sobre a indexação salarial, ou seja, há uma regulamentação dos preços do trabalho;

c) Políticas estruturais indiretas que compreendem as políticas macroeconômicas que estimulam a expansão da produção. Estas políticas englobam desde investimentos públicos diretos até políticas orientadas para reduzir 
a taxa de juros e subsídios para investimentos em capital físico produtivo;

d) Políticas estruturais diretas voltadas para a redução do desemprego e aumento da produtividade. O objetivo é transformar trabalhadores ou postos de trabalho, aumentando o número de postos existentes, melhorando a sua qualidade ou aumentando a qualificação da força de trabalho. Neste grupo, incluem-se os programas de crédito produtivo a micro e pequenas empresas, programas de treinamento e programas de intermediação de mão-de-obra.

Braga e Toneto Jr. (2000) defendem o surgimento do Programa de Geração de Emprego e Renda (PROGER), como programa federal de microcrédito que visava estimular o emprego a partir dos pequenos e microempreendimentos com base nos recursos do FAT-Fundo de Amparo ao Trabalho. O PROGER atendia além das micro e pequenas empresas, os recém-formados, abrindo ainda possibilidade de atendimento ao setor informal. Embora Inicialmente atendesse apenas às atividades urbanas, posteriormente criou-se o PROGER - Rural. O Programa introduziu algumas inovações em relação às linhas de finaniamento tradicionais, aproximandoo das experiências internacionais de microcrédito. Deve-se destacar, em relação a este aspecto, a operacionalização descentralizada, a existência de critérios de controle social e programas de treinamento e acompanhamento dos beneficiários acoplados ao financiamento.

É importante salientar que Matos et al (2014) estabelecem que o microcrédito estaria situado entre os limites de programas sociais de combate à pobreza parcialmente ou largamente subsidiados, nunca completamente subsidiados, e programas totalmente autossustentáveis financeiramente que fomentam a criação e expansão de pequenos negócios economicamente viáveis. Ainda estabelecem que acesso ao mercado de crédito e serviços financeiros por meio da oferta de produtos voltados para os mais pobres constituiu-se uma modalidade nova e prioritária da política social do período neoliberal, depois de 1980.

Vale ressaltar ainda que Matos et al (2014) esclarecem que o microcrédito não se trata de uma ação filantrópica, doação ou mesmo simples transferência de renda. Para eles tampouco há a ideia de assistencialismo ou tratamento paternalista, 
configurado nas políticas e nos programas públicos como "a fundo perdido", mas trata-se de promover uma nova relação emancipatória e de confiança, mais permanente e devidamente adequada entre os "tomadores de crédito" e as organizações financeiras, sejam governamentais, do setor privado ou da sociedade civil.

Para Costanzi e Passos (2005), o microcrédito tem se tornado uma dos principais expoentes das politicas públicas de trabalho e rendo em todo o mundo, e em função disso requer a consideração de três elementos fundamentais: (i) a focalização nos pobres ou microempreendedores de baixa renda sem acesso ao crédito formal; (ii) a forma peculiar e adequada ao público-alvo de entrega do crédito; c) o mecanismo autossustentável de combate a pobreza e a exclusão social. Com isso, segundo a autora, o microcrédito, deve ser considerado não somente um instrumento de geração de trabalho e renda, como também um mecanismo de democratização do crédito.

Costanzi e Passos (2005) defendem ainda que na avaliação ex post dessa política pública, verificou-se que entre julho e setembro de 2013, foram realizadas 1.090.513 operações de microcrédito, atendendo 1.092 .585 clientes, resultados superiores em $34,58 \%$ e em $20,51 \%$, respectivamente, ao observado no $3^{\circ}$ trimestre de 2012. Ao longo de 2013, 3.161 .023 clientes foram atendidos pelo PNMPO, representando 3.128.421 operações: números significativamente superiores à execução realizada nos três primeiros trimestres de 2012 segundo relatórios gerencias do PNMPO-3ํㅜㄴIMESTRE, 2013.

Enquanto política pública é importante salientar com Kraychete (2005), que a constituição de um mercado de microfinanças não se torna uma realidade em função unicamente da constituição de leis, mas como qualquer outro mercado, sua formação é desenvolvimento acontecem em um espaço social e politicamente construído. 


\subsection{Percepções sobre o Microcrédito}

Como vimos anteriormente, o microcrédito deve ser visto não somente sob a ótica econômica, mas também como uma política pública de combate à pobreza, por meio da geração de emprego e renda, promovendo o empoderamento pessoal e consequente transformação social. No entanto, a literatura brasileira sobre os resultados da política pública de microcrédito podem apresentar divergências, sendo alguns autores otimistas com os resultados e outros não tanto.

Para Barone et al (2002) há forte impacto positivo do microcrédito nas situações de pobreza, pois permite o o acesso continuado ao crédito para negócios com capital próprio mínimo, fortalecendo o empreendimento. Como resultado disso, se verifica aumento da renda familiar, o que resulta muitas vezes, na volta do filho para a escola, na construção de novos cômodos na casa e a melhoria da qualidade da alimentação familiar.

Defendem ainda que o

"microcrédito vem apoiando modelos alternativos de geração de ocupação e renda para o segmento mais pobre da população, ... que ele se constitua em alternativa às tendências mais gerais da sociedade contemporânea de concentração da renda e ampliação das disparidades sócio-econômicas". (BARONE et al, 2002)

Opinião otimista em relação ao microcrédito pode ser vista em Lima (2009) quando conclui que

"o microcrédito vem sendo, nas últimas décadas, um importante instrumento para viabilizar a constituição e a manutenção de micro e pequenos negócios economicamente sustentáveis. As inovações desenvolvidas no âmbito das IMFs, ao criarem substitutos para os colaterais financeiros, permitem o acesso ao crédito por parte daqueles que não têm garantias reais a oferecer."

\section{$[\ldots]$}

"A concessão de microcréditos estimula a autonomia e a capacidade empreendedora do beneficiário. As práticas adotadas pelas IMFs, baseadas, entre outros aspectos, na atuação do agente de crédito, 
permitem a criação de uma relação de responsabilidade e confiança entre 0 beneficiário e a instituição que concede o crédito" (LIMA, 2009)

Matos et al (2014) verificam que os estudiosos sobre o tema convergem no sentido de que o microcrédito é um instrumento de combate à pobreza, uma vez que permite aos empreendedores terem opção de crédito diferente da comum agiotagem, em que sofrem com as taxas de juros exorbitantes.

Para Manos (2009), o formato do microcrédito reduz os custos com monitoração de contratos e avaliação de garantias, decorrentes do risco de inadimplência, o que promove a redução da taxa de juros. Para a autora, "o arranjo contratual do microcrédito pode reduzir o custo do dinheiro ao tomador final e ampliar a oferta de crédito na economia". E considera ainda que no Brasil, "onde as micro e pequenas empresas possuem peso significativo no Produto Interno Bruto (PIB) e no emprego da mão-de-obra obra, ... a metodologia do microcrédito é um indispensável instrumento para geração de emprego e renda."

Por outro lado, Manos (2009) considera que

"apesar de reduzir os problemas decorrentes das assimetrias de informação, o microcrédito não seja capaz de reduzir tão significativamente a taxa de juros de modo que se amplie em escala relevante o acesso ao crédito por empreendimentos de baixa renda e lucratividade - que são o público-alvo dos programas de concessão de microcrédito."

Também Matos et al (2014) ressaltam a conclusão de Toscano (2001) que

"Como extensão do sistema financeiro, o microcrédito jamais servirá como mecanismo de combate à pobreza". Mais ainda, esse autor assegura que aportar microcrédito pode viabilizar pequenos empreendimentos individuais, mas nunca será suficiente para estruturar um processo de desenvolvimento socioeconômico local, pois: [...] falta-Ihe a necessária articulação com políticas públicas voltadas à promoção do resgate político de imensa parcela da população que vive na informalidade, excluída, portanto, do mercado capitalista tradicional, quer como produtores, quer como trabalhadores e consumidores." (MATOS et al, 2014) 
E ainda Braga e Toneto Jr. (2000) defendem que o desenvolvimento de um programa de microcrédito só tem sentido se este for inserido dentro de um plano de geração de emprego e renda mais amplo, com participação não apenas do governo, mas de outros segmentos da sociedade civil. Bem como promover atividades de suporte e capacitação para os empreendedores atendidos.

A parceria entre os diversos atores públicos e a sociedade civil tem sido utilizadas para promover políticas publicas de geração de emprego e renda eficazes, de maneira focalizada e direcionada. Temos portanto, exemplo o envolvimento de organizações não-governamentais ONGS que a partir da estruturação e participação popular são capazes de desenvolver projetos que promovam o bem estar dos envolvidos, tanto que tais organizações em geral, obtêm financiamentos para realizar seus projetos, inclusive de microcrédito.

Desta forma, é mais comum a parceria das diversas esferas governamentais com a sociedade civil para a promoção de programas de microcrédito facilitando o acesso de micro e pequenos empreendedores formais e informais ao crédito produtivo. Com isso, Braga e Toneto Jr. (2000) defendem que o crescimento do sistema de microcrédito no Brasil não precisa necessariamente apoiar-se em subsídios governamentais, que oneram governos e muitas vezes criam uma rede de favorecimentos baseados não em critérios técnicos, mas políticos.

\subsection{Microcrédito e Empreendedorismo}

Ao lado do microcrédito outro tema que tem sido bastante discutido no Brasil, é o empreendedorismo no que se refere às micro e pequenas empresas e aos empreendedores informais e sua contribuição para a economia do país, com a geração de empregos e renda. Desta forma, é imprescindível identificar como o microcrédito tem contribuído para o desenvolvimento empreendedor do Brasil. Puga (2000) estabelece que a importância das pequenas e médias empresas se dá na geração de empregos e de divisas, na melhoria da distribuição de renda e na propositura de inovações, enquanto 
Nesta linha, Organizaçao Internacional do Trabalho (OIT) defende que as MPEs são determinantes não só para o crescimento econômico, como também para o desenvolvimento social e, são ainda, cada vez mais responsáveis pela criação de postos de trabalho em todo mundo. Segundo dados apresentados em 2014, havia 9 milhões de micro e pequenas empresas no Brasil.

Também o Serviço Brasileiro de Apoio As Micro e Pequenas (SEBRAE) empresas, essa categoria de negócios vêm progressivamente aumentando sua relevância na economia brasileira. Constatou-se que em termos agregados esta participação era de 21\% em 1985, aumentou para 23\% em 2001 e para 27\% em 2011. Esta participação aumentou tanto em serviços como no comércio tendo se reduzido um pouco na atividade industrial, onde predominam médias e grandes empresas que se beneficiam de economias de escala.

A importância das MPEs no período 2009-2011 é realçada em todas as dimensões e em todas as atividades:

- No Setor de Serviços as MPEs geraram 36,3\% do total do valor adicionado do setor; representavam $98,1 \%$ do número de empresas; empregaram $43,5 \%$ dos trabalhadores; e, pagaram $27,8 \%$ das remunerações de empregados no período;

- No Setor de Comércio as MPEs geraram 53,4\% do total do valor adicionado do setor; representavam $99,2 \%$ do número de empresas; empregaram $69,5 \%$ do pessoal ocupado no setor; e, pagaram 49,7\% das remunerações dos empregados do setor no período;

- No Setor Industrial as MPEs geraram 22,5\% do valor adicionado do setor; representavam $95,5 \%$ do número de empresas; empregaram $42 \%$ do pessoal ocupado no setor; e pagaram $25,7 \%$ das remunerações de empregados no período.

Para Kotesky (2004), diferentes fatores contribuem para a crescente participação desse tipo de empresa na economia brasileira, como a globalização, fenômeno exige que as grandes empresas, ao buscarem uma maior eficiência, terceirizem as atividades de apoio ao negócio principal; absorção de mão-de-obra demitida das grandes empresas em decorrência de avanços tecnológicos; constatação de gradual redução nas taxas de mortalidade de micro e pequenos 
estabelecimentos e uma expressiva taxa de natalidade de microempreendimentos; estruturas flexíveis que permitem responder melhor e mais rapidamente às crises econômicas; e exigência da modernidade, que requer empresas mais enxutas, menores e com maior índice de produtividade.

E segundo estudos do Macedo et al (2015) apresentados no Relatório Global Entrepreneurship Monitor (GEM), considerando mais de uma década de monitoramento do empreendedorismo no Brasil, o tema empreendedorismo tema continua como um dos mais relevantes no cenário econômico e social país. Segundo a pesquisa, em 2015, o Brasil atingiu a a maior taxa de empreendedorismo da série histórica, identificando que em cada dez brasileiros, entre 18 e 64 anos, quase quatro possuem um negócio ou realizaram alguma ação, no último ano, visando criar um negócio.

A Constituição Brasileira de 1988 no sentido de favorecer a livre iniciativa, previa em seus dispositivos atendimento diferenciado as empresas de pequeno porte constituídas sob leis brasileiras e que tenham sua sede e administração no País, conforme se verifica

A União, os Estados, o Distrito Federal e os Municípios dispensarão às microempresas e às empresas de pequeno porte, assim definidas em lei, tratamento jurídico diferenciado, visando a incentiválas pela simplificação de suas obrigações administrativas, tributárias, previdenciárias e creditícias, ou pela eliminação ou redução destas por meio de lei. (Constituição Federal, art. 179: 1988)

A partir deste dispositivo constitucional, o crescimento empreendedor, a necessidade de valorizar as micro e pequenas empresas, e diversidade de legislações estaduais e municipais, o Governo Federal instituiu em 2006 o Estatuto das Micro e Pequenas Empresas mediante a Lei Complementar № 123, de 14 de Dezembro de 2006, estabelecendo normas gerais relativas ao tratamento diferenciado e favorecido a ser dispensado às microempresas e empresas de pequeno porte no âmbito dos Poderes da União, dos Estados, do Distrito Federal e dos Municípios.

São objetivos do Estatuto, estabelecer normas relativas: a) tributação em 
regime único; b) ao cumprimento de obrigações trabalhistas e previdenciárias, inclusive obrigações acessórias; c) ao acesso a crédito e ao mercado, inclusive quanto à preferência nas aquisições de bens e serviços pelos Poderes Públicos, à tecnologia, ao associativismo e às regras de inclusão; d) ao cadastro nacional único de contribuintes.

Em termos gerais, essa legislação veio para pacificar o tratamento dispensado às micro e pequenas empresas, partindo da definição de microempresas ou empresas de pequeno porte, a sociedade empresária, a sociedade simples, a empresa individual de responsabilidade limitada e o empresário com faturamento anual de até $R \$ 360.000,00$ (trezentos e sessenta mil reais) para microempresas, e de $360.000,01$ (trezentos e sessenta mil reais e um centavo) até 4.800.000,00 (quatro milhões e oitocentos mil reais).

No que se refere ao crédito a Lei prescreve:

Art. 57. O Poder Executivo federal proporá, sempre que necessário, medidas no sentido de melhorar o acesso das microempresas e empresas de pequeno porte aos mercados de crédito e de capitais, objetivando a redução do custo de transação, a elevação da eficiência alocativa, o incentivo ao ambiente concorrencial e a qualidade do conjunto informacional, em especial o acesso e portabilidade das informações cadastrais relativas ao crédito.

Art. 58. Os bancos comerciais públicos e os bancos múltiplos públicos com carteira comercial, a Caixa Econômica Federal e o Banco Nacional do Desenvolvimento Econômico e Social BNDES manterão linhas de créditoespecíficas para as microempresas e par a as empresas de pequeno porte, vinculadas à reciprocidade social, devendo o montante disponível e suas condições de acesso ser expressos nos respectivos orçamentos e amplamente divulgados.

[...]

$\S 2^{\circ} O$ acesso às linhas de crédito específicas previstas no caput deste artigo deverá ter tratamento simplificado e ágil, com divulgação ampla das respectivas condições e exigências. (BRASIL, 2006)

Outro avanço importante na valorização do empreendedorismo nacional se deu a aprovação da Lei Complementar № 128, de 19 de dezembro de 2008 que 
incluía no Estatudo da Micro e Pequena Empresa de 2006, a figura do Microemprendedor Individual-MEI, isto é, "o empresário individual ou empreendedor que exerça as atividades de industrialização, comercialização e prestação de serviços no âmbito rural, que tenha auferido receita bruta, no anocalendário anterior, de até $R \$ 81.000,00$ (oitenta e um mil reais) (BRASIL, 2008)

Apesar dos dispositivos legais que propiciaram um ambiente favorável às micro e pequenas empresas e empreendedores em geral, estudos demonstram que há taxa de mortalidade entre elas é elevado. No entanto, tais estudos atestam uma leve diminuição nessa taxa, conforme indica SEBRAE (2013), em que a taxa de sobrevivência das empresas constituídas em 2007 foi de 75,6\%, nível superior ao verificado no grupo das empresas constituídas em 2005 e 2006, cujas taxas de sobrevivência foram, respectivamente, $73,6 \%$ e $75,1 \%$. Tais resultados estão, segundo o estudo, em sintonia com os avanços verificados tanto no âmbito dos negócios (p.ex. com a tendência à melhora na legislação em favor das MPE), quanto no que diz respeito à evolução das características dos próprios empreendedores brasileiros.

Em outro estudo, SEBRAE (2004) elenca os principais fatores de sucesso apontados pelos empresários, que foram agrupados segundo três características comuns:

1) Habilidades gerenciais: Bom conhecimento do mercado onde atua, Boa estratégia de vendas

2) Capacidade empreendedora: Criatividade do empresário, Aproveitamento das oportunidades de negócios

3) Logística operacional: Escolha de um bom administrador, Uso de capital próprio, Reinvestimento dos lucros na empresa.

Os primeiros dois fatores apontados integram as chamadas Habilidades Gerenciais, que refletem a preparação do empresário para interagir com o mercado em que atua e a competência para bem conduzir o seu negócio. O terceiro conjunto de fatores determinantes do sucesso representa a Logística Operacional Operacional do empresário, fornecendo as bases para a criação, sustentação e crescimento da atividade empresarial. 
Considerando apenas a categoria Logística Operacional, o estudo demonstrou que $29 \%$ dos entrevistados relacionaram a importância do capital de giro como fator crítico de sucesso, embora este fator esteja abaixo dos em grau de importância dos fatores vinculados as outras duas categorias.

Por outro lado, no mesmo estudo, uma parcela dos empresários que encerraram as atividades da empresa foi entrevistada pela pesquisa, possibilitando a avaliação das principais causas da mortalidade precoce das empresas. Diante de doze questões para escolha dos entrevistados, $42 \%$ indicaram em primeiro lugar entre as causas do fracasso questões relacionada a falhas gerenciais na condução dos negócios, expressas nas razões: falta de capital de giro (indicando descontrole de fluxo de caixa), e $21 \%$ problemas financeiros (situação de alto endividamento).

Isso demonstra a importância da microcrédito como fator de redução da mortalidade das micro e pequenas empresas, uma vez que o empresário diante da dificuldade de caixa não consegue apoio da instituições bancárias tradicionais, podendo se endividar mais ainda utilizando outras fontes de recursos. 


\section{MICROCRÉDITO E EMPREENDEDORISMO NO DISTRITO FEDERAL}

Quando em $1^{\circ}$ ㅇ de maio de 1957 mandou celebrar a Primeira Missa no Cruzeiro de onde partiria a construção da nova sede do Governo Brasileiro, não imaginava o grande polo de empreendedorismo que se tornaria o Distrito Federal.

Com uma população estimadada em 2.977.216 segundo o IBGE, espalhada em aproximadamente $5.780 \mathrm{~km}^{2}$, o Distrito Federal é hoje um espaço de oportunidades, e se durante muitos anos, manteve a fama de cidades dos concursos públicos, atualmente não só os concursos estão no imaginário dos brasilienses ou daqueles que aqui chegam, mas também a possibilidade de empreender. Com a missão de impulsionar a ocupação demográfica e econômica da região central do país, o Distrito Federal tornou-se um polo de desenvolvimento da sua região de influência e também da Região Centro-Oeste e Sudeste nas áreas que compõem a Região Integrada de Desenvolvimento do Distrito Federal e Entorno (RIDE/DF)

Segundo estudos da Codeplan (2015), o desenvolvimento econômico do DF é marcado por três fases. A primeira, corresponde ao período que se inicia com a inauguração de Brasília, em que a construção civil foi o principal setor de absorção de mão de obra local, nas décadas de 1960 e 1970. A segunda, com a consolidação de Brasília, sede do Governo Federal, deu ao setor público maior representatividade na composição do PIB regional na década de 1980, principalmente com a finalização da transferência dos órgãos públicos e respectivos servidores. Na terceira e última fase, a partir da década de 1990, a economia sustenta-se no comércio, setor público e principalmente nos serviços em geral.

Embora o Distrito Federal seja limitado territorialmente para desenvolver de forma extensiva as atividades do setor primário e de não disponha de muitas opções para industrializar-se sem comprometer o seu meio ambiente, o PIB, calculado pela Codeplan/DF em parceria com o Instituto Brasileiro de Geografia e Estatística (IBGE) conforme Distrito Federal (2014), alcançou o montante de $\mathrm{R} \$ 175,4$ bilhões em 2013, a preços correntes, último ano divulgado. A atividade econômica da população encontra-se concentrada na prestação de serviços $(93,3 \%)$ contra apenas $6,5 \%$ na indústria e menos de 1\% no Setor Agropecuário. 
O PIB per capita do DF é o mais alto do Brasil, embora a sua participação no PIB nacional seja de apenas 3,3\%.

\section{Figura 2 - Distribuição do PIB no Distrito Federal em 2013}



Fonte: Distrito Federal, 2014

Verifica-se ainda que o Distrito Federal, superou atingiu em 2014 segundo maior Índice de Desenvolvimento Humano do país entre 16 regiões metropolitanas analisadas, atrás apenas de São Paulo e seguida de Curitiba.

Há o ainda seguimento de comércio local e internacional. O comércio exterior do Distrito Federal é essencialmente importador, sendo que no ano de 2014 o valor das importações foi da ordem de US\$1,2 bilhão e as exportações, US\$ 330.7 milhões. As carnes de galos/galinhas, cortadas em pedaços, lideram o ranking de produtos mais exportados pelo DF, vindos em seguida a soja e os combustíveis e lubrificantes para aeronaves. Os maiores importadores do DF em 2014 foram Arábia Saudita, Venezuela e China.

Segundo a Pesquisa de Emprego e Desemprego do Distrito Federal PED/DF (realizada pela Secretaria de Estado de Trabalho - SETRAB em convênio 
com o DIEESE e a Codeplan/DF), a População Economicamente Ativa do DF em dezembro de 2014 era de 1.511 mil. Já a estimativa de pessoas ocupadas era de 1.334 mil e os desempregados totalizavam 177 mil, número que vem decrescendo a partir de 2004.

\section{Figura 3 - População Ocupada Segundo Setores de Atividades - 2014}

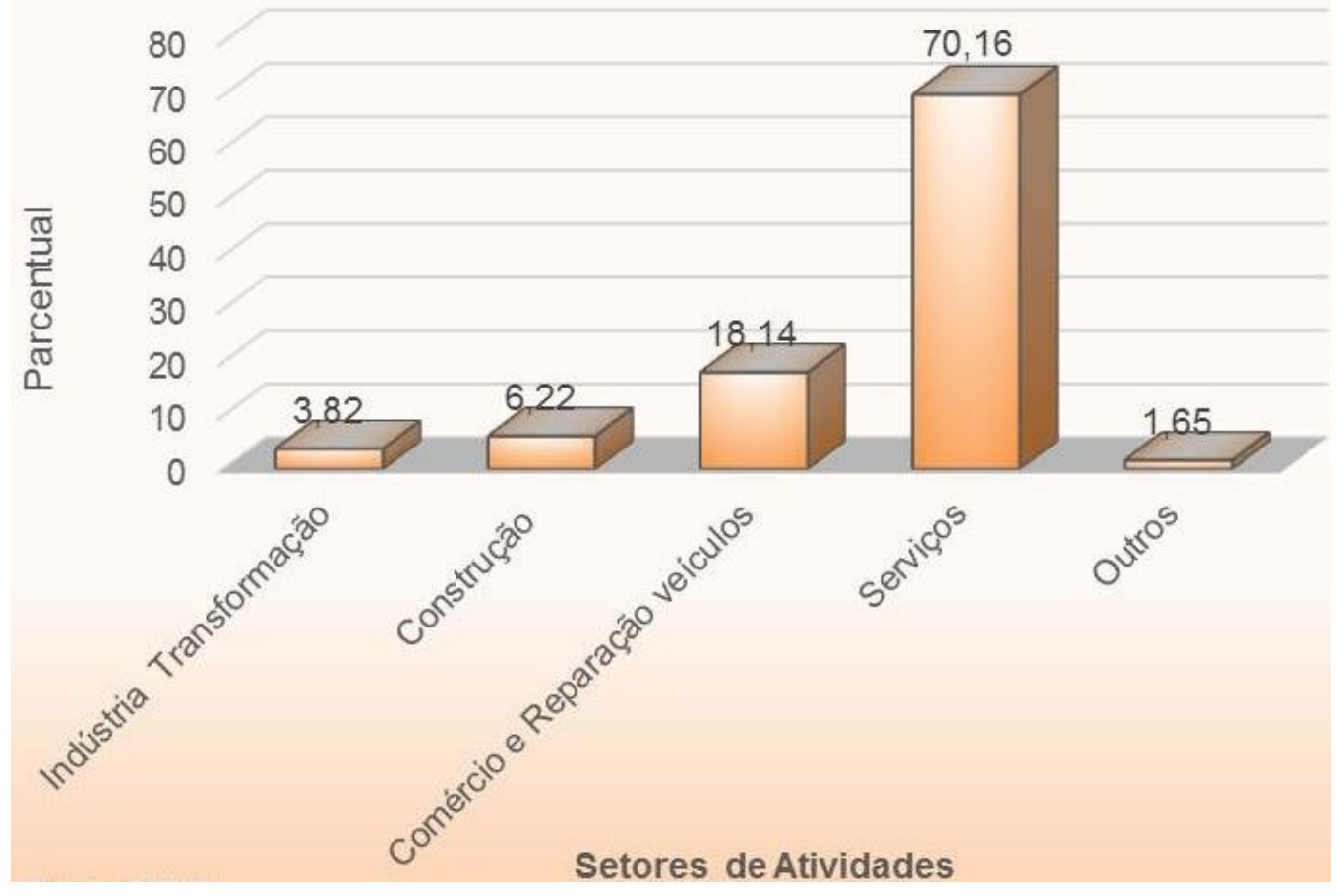

Fonte: Distrito Federal, 2014

Ainda conforme Distrito Federal (2014), a População Economicamente Ativa do DF em dezembro de 2014 era de 1.511 mil. Já a estimativa de pessoas ocupadas era de 1.334 mil e os desempregados totalizavam 177 mil, número que vem decrescendo a partir de 2004. O fato de Brasília ser a Capital do país e desempenhar preponderantemente funções institucionais e administrativas, a atividade econômica da população concentra-se na prestação de serviços, $70,16 \%$, incluindo o comércio, $18,14 \%$, enquanto a agropecuária, a indústria, seja de transformação ou construção civil são menos expressivas.

De acordo com Codeplan (2015), o Distrito Federal possui um expressivo mercado consumidor, com 2,9 milhões de pessoas e, o mais importante, com uma renda média três vezes maior que a média nacional. A população de sua área 
metropolitana já supera 4,1 milhões de habitantes, considerando que sua periferia metropolitana, formada por 12 municípios goianos adjacentes, possui contingente populacional de 1,2 milhão.

\subsection{Perfil das Empresas e Ocupações no Distrito Federal}

Dados da Secretaria de Estado de Fazenda do Distrito Federal, há registrados junto ao órgão, um total de 238.967 contribuintes de ICMS ou ISS. O órgão elabora relatório mensal apresentando a situação de registro empresarial e perfil de tributação que demonstram a divisão dos diversos contribuintes pessoas físicas e pessoas jurídicas conforme tabelas a seguir.

Tabela 1 - Contribuintes Pessoa Física DF

\begin{tabular}{|c|c|c|}
\hline Categoria do Contribuinte & Quantidade & $\%$ \\
\hline Feirantes/Ambulantes & 2.712 & $19 \%$ \\
\hline Produtor Rural & 3.780 & $27 \%$ \\
\hline Profissionais Autônomos & 7.606 & $54 \%$ \\
\hline & $\mathbf{1 4 . 0 9 8}$ & $\mathbf{1 0 0 \%}$ \\
\hline
\end{tabular}

Fonte: Secretaria de Fazenda do DF, 2016

O relatório apresenta ainda as pessoas jurídicas enquadradas no Estatuto da Micro e Pequena Empresa, vinculadas aos Regimes Especiais de Tributação denominados Simples Nacional destinado às micro e pequenas empresas, e e Sistema de Recolhimento em Valores Fixos Mensais dos Tributos Abrangidos pelo Simples Nacional (Simei), voltado aos microempreendedores individuais, como segue. 
Tabela 2 - Contribuintes do Distrito Federal por Regime de Tributação

\begin{tabular}{|c|c|c|}
\hline Regime de Apuração & Quantidade & $\%$ \\
\hline Simples Nacional & 67439 & $38 \%$ \\
\hline SIMEI & 109820 & $62 \%$ \\
\hline Total & $\mathbf{1 7 7 2 5 9}$ & $\mathbf{1 0 0} \%$ \\
\hline
\end{tabular}

Fonte: Secretaria de Fazenda do DF, 2016

Os dados do perfil sócio-demográfico mostram um Distrito Federal com alto potencial empreendedor por um lado, porém com taxas de desocupação elevadas, o que leva a inferir que existe uma demanda potencial para os programas de microcrédito. Também os dados de registro empresarial e regimes de tributação mostram que há empresas de micro e pequeno porte registradas que compõem o publico-alvo empresarial dos programa de microcrédito.

Os programa de microcrédito do Distrito Federal devem ser orientados a proporcionar não somente o acesso ao crédito, como também orientação, capacitação e acompanhamento durante todo o processo de obtenção do financiamento e gerenciamento dos recursos na geração de trabalho e renda.

Desta forma, torna-se crucial, desenvolver estratégias de fomento às mais distintas atividades produtivas. Dadas as peculiaridades da economia local, em particular a elevada renda per capita de sua população, um dos segmentos que apresenta maior potencial de expansão é o das micro e pequenas empresas.

\subsection{A Oferta de Microcrédito no Distrito Federal}

A partir da apresentação dos dados quantitativos na seção anterior passamos a discutir a realidade do microcrédito no Distrito Federal, considerando experiências existentes ou que deixaram de existir no âmbito público. 


\subsubsection{Programa Providência para Elevação da Renda Familiar}

O Programa Providência para Elevação da Renda Familiar é uma entidade sem fins lucrativos, criada no âmbito da Arquidiocese de Brasília, da Igreja Católica, tendo por missão atuar como agente transformador da sociedade, promovendo a inserção social e capacitação profissional, por meio da concessão de microcrédito a profissionais carentes e sem acesso ao crédito das instituições financeiras convencionais.

O Programa Providência é entidade filantrópica, beneficente, sem fins lucrativos, criada em 02.02.1998, inscrita no Ministério da Justiça como Organização da Sociedade Civil de Interesse Público OSCIP, no CNAS Conselho Nacional de Assistência Social, no CAS-DF Conselho de Assistência Social do Distrito Federal, no PNMPO Programa Nacional de Microcrédito Produtivo Orientado do Ministério do Trabalho e Emprego, como OS Organização Social no âmbito do Governo do Distrito Federal e registrado no CDI Conselho dos Direitos do Idoso vinculado à Secretaria de Justiça, Direitos Humanos e Cidadania do Distrito Federal.

O patrimônio do Programa Providência é constituído dos bens e direitos adquiridos ou que lhe forem doados, legados ou cedidos em caráter definitivo e dos que venham a ser incorporados a qualquer título, conforme estatuto social.

Além da concessão de microcrédito, o Programa Providência inaugurou em 2014, um centro de atividades de caráter social voltadas para grupos de pessoas aposentadas ou com mais de 60 anos de idade, tendo em vista a sua valorização, a sua satisfação e seu pleno desenvolvimento pessoal, social, intelectual, cognitivo e afetivo.

Segundo Escobar et al (2016) conforme informações do relatório anual, a carteira de operações de microcrédito do Programa Providência apresentou ao final do ano o saldo de $\mathrm{R} \$ 389.236,81$, com redução de 2,4\%, em relação a 2014 . Durante o ano de 2015 foram deferidas 196 operações de microcrédito, no valor total de $R \$ 557.500,00$, sendo $68,4 \%$ destinados ao comércio, $13,1 \%$ para a produção e $18,5 \%$ para serviços. O maior percentual de concessão foi oferecido às mulheres, 
totalizando $64,8 \%$ dos créditos concedidos. $96,9 \%$ foram para capital de giro, 3,1\% foram alocados para investimento.

As operações de microcrédito do Programa Providência são dirigidas a famílias de baixa renda que sejam empreendedoras. Seu objetivo, portanto, é gerar produção para elevar a renda familiar e ocupar as pessoas. O programa Providência atua com grupos de 3 a 5 membros, no sistema de fiança solidária, desta forma, do total de operações concedidas no exercício, 48 foram realizadas sob a forma de crédito grupal de tomadores - mediante a utilização do mecanismo do aval solidário , envolvendo 149 beneficiários e atingindo o valor de $R \$ 408.500,00$; enquanto os financiamentos individuais - 47, ao todo somaram $R \$ 149.000,00$.

\subsubsection{Programa Prospera}

PROSPERA é a denominação atual da linha de microcrédito produtivo orientado do Governo do Distrito Federal, sendo estabelecida pela primeira vez em 1995 com a Lei Complementar № 005, de 14 de Agosto de 1995, denominado oficialmente Fundo de Solidariedade para a geração de emprego e renda FUNSOL/DF, prevendo legalmente

"I - à concessão de empréstimos e financiamentos a: "a) microprodutores urbanos ou rurais, artesãos, pequenos prestadores de serviços, feirantes e setor informal;

"b) cooperativas ou formas associativas de produção ou de trabalho;

"c) microempresas e empresas de pequeno porte;

"Il - à capacitação e ao treinamento gerencial de empreendedores econômicos, bem como à assistência técnica;

"III - à formação de mão-de-obra e à preparação de jovens para o primeiro emprego;

"IV - ao aval das operações que objetivem a geração de emprego e renda;

"V - ao financiamento de programas governamentais de geração de emprego e renda."; (DISTRITO FEDERAL, 1995) 
A legislação do FUNSOL/DF previa empréstimos e financiamentos de até $\mathrm{R} \$ 10.000$ para empreendimentos urbanos (pessoa física ou jurídica), com taxas de juros de até 12\%aa mais TJLP, podendo conceder prazos de até 24 meses com carência de até 6 . $E$ na carteira rural, a previsão legal era de $R \$ 10.000,00$ por produtor ou grupo de produtores, com prazos de até 72 meses, e taxas de juros de até $12 \%$ aa mais TJLP. Durante longos anos, regidos por esta legislação, o nome fantasia da linha de microcrédito era Creditrabalho ou ainda Banco do Trabalho.

Em função de escândalos envolvendo gestores públicos e políticos vinculados ao Fundo nos exercício de 1999 e 2000, conforme se verifica em Rodrigues (2014), o Programa foi suspenso, sendo retomado em 2005, mediante a publicação da Lei Complementar № 704 de 18 de janeiro de 2005, e transferência dos recursos depositados no FUNSOL para Fundo de Geração de Emprego e Renda. E subsidiariamente à lei complementar foi estabelecido o Decreto № 25.745, de 11 de abril de 2005 e resoluções legais posteriores.

A legislação do FUNGER incluía alguns dispositivos no sentido de ampliar o público-alvo do microcrédito, como a inclusão de recém-formados como público-alvo do Programa. Na carteira urbana, ampliava os valores de concessão para a) $\mathrm{R} \$ 10.000,00$ para empreendedores pessoa física; b) $\mathrm{R} \$ 20000,00$ para micro e empresas de pequeno porte, c) $\mathrm{R} \$ 50.000,00$ para cooperativas. Na carteira rural disponibilizava $\mathrm{R} \$ 10.000,00$ por produtor, bem como redução do prazo para até 48 meses, mais 12 de carência. No entanto, houve redução pela metade das taxas utilizadas nas operações urbanas e rurais.

A previsão legal do FUNGER continua válida até os dias atuais como pequenos acréscimos que visam ampliar e facilitar a concessão de microcrédito. Atualmente o Fundo é administrado por um Conselho de Administração, que tem como presidente o Secretário de Trabalho do DF, sendo composto por instituições governamentais e não-governamentais, como Secretaria de Estado da Fazenda, Secretaria de Estado da Agricultura, Pecuária e Abastecimento, Secretaria de Estado de Desenvolvimento Econômico, Secretaria de Estado de Ciência e Tecnologia, Federação das Indústrias de Brasília - FIBRA, Federação do Comércio - FECOMÉRCIO e Centrais Sindicais. A administração do fundo cabe ao Banco de 
Brasília S/A, onde os recursos são mantidos, e que atua como agente financeiro, mediante remuneração.

\subsubsection{Público-alvo}

O microcrédito Prospera, conforme legislação específica, atende diversos perfis de empreendedores formais e informais afim de oportunizar crédito produtivo a quem precise.

Dessa forma, constituem público do Programa empreendedores da área urbana quanto rural:

a) Área Urbana

- Empreendedores urbanos do setor informal - ambulantes, feirantes, profissionais autônomos;

- Microempreendedor Individual - MEl;

- Microempresas ou empresas de pequeno porte;

- Cooperativas de trabalho e produção;

-Artesãos.

-Recém-formados

b) Área Rural

- Produtor Rural Familiar;

- Cooperativas de trabalho ou produção.

As concessões voltadas à área rural são executadas pela Empresa de Assistência Técnica e Extensão Rural do Distrito Federal (EMATER/DF), sobordina à Secretaria de Estado de Trabalho.

Para garantir que o crédito será utilizado de forma produtiva, evitando uso indevido, os empreendimentos devem ter pelo menos seis meses de efetivo funcionamento, comprovados por meio de verificação de documentos de compras, referências comerciais entre outros. No entanto, empreendimentos iniciantes podem obter a concessão desde que apresentam planejamento, como plano de negócios, ou outros instrumento que contribua para demonstrar a viabilidade econômica do 
projeto ou curso de gestão de negócios. O objetivo dessa exigência é incentivar a aquisição de competência pelos futuros empreendedores, bem como facilitar a análise para concessão.

Considerando se tratar de um crédito com recurso público oriundos dos cofres do Distrito Federal, há impedimento legal para tomadores com dívidas na Fazenda Pública do DF, e também com restrição cadastral junto aos serviços de proteção ao crédito conforme prevê a legislação específica.

\subsubsection{Destinatários Especiais do Microcrédito}

Por meio do Decreto № 25.745, de 11 de abril de 2005 e resoluções legais posteriores, o Programa Prospera possibilitou o atendimento de empreendedores com restrição cadastral vinculados a programas sociais do Governo do Distrito Federal como DF Sem Miséria e posteriormente do Governo Federal como Bolsa Família, com valores menores e taxas menores associados a prazos mais dilatados, diferenciando -se do tratamento dado aos outros públicos atendidos.

\subsubsection{Crédito Individual e em Grupos Solidários}

A concessão do microcrédito pode ser realizada por tomador individual ou por grupos de tomadores de forma solidária. Na concessão individual é necessário a apresentação de fiador, enquanto na concessão solidária os membros se autoavalizam, assumindo os riscos conjuntamente.

$\mathrm{Na}$ concessão em grupo pode incluir entre 3 e 5 participantes e cada integrante pode exercer atividade diversa dos demais e aplicar os recursos individualmente, ou ainda em parceria com os outros. No entanto, aplicação dos recursos fica vinculada à indicação dada pelo solicitante durante o atendimento. A escolha dos membros que comporão o grupo cabe exclusivamente aos tomadores que em geral, escolhem um membro para liderar o grupo. 
Embora clientes com restrição cadastral junto aos serviços de proteção ao crédito fiquem impedidos de participar do Programa, a legislação atual prevê a excepcionalidade nos casos de grupos solidários, em que um integrante pode ter restrição desde que os demais assim o permitam mediante declaração específica, e desde que o valor da dívida para com terceiros não seja superior ao próprio crédito a ser obtido.

\subsubsection{Finalidade do Crédito}

Conforme legislação específica os recursos obtidos a título de microcrédito do Programa Prospera podem ser aplicados como
A) Capital de Giro:
- Aquisição de mercadorias e de matérias-primas
B) Custeio Agrícola:

- Aquisição de insumos - compra de sementes, defensivos, preparação de solo, adubos, etc.

C) Investimento (Urbanos e rurais):

- $\quad$ Aquisição de ferramentas, máquinas e equipamentos;

- Recuperação e/ou conserto de máquinas e equipamentos;

- Recuperação e/ou conserto de veículos utilitários, efetuados por empresa idônea e que dê garantia dos serviços realizados.

- Melhoria e/ou ampliação de instalações próprias, desde que comprovadamente destinadas ao negócio;

Há vedação legal conforme previsão a legislação para pagamento de dívidas anteriores, veículos de passeio entre outros

Art. 17. Os créditos do FUNGER/DF serão concedidos a projetos que estejam de acordo com as diretrizes estabelecidas pelo Conselho de Administração do FUNGER/DF, vedada a alocação de recursos para:

I - o pagamento de dívidas ou de encargos financeiros; 
II - a recuperação de capitais já investidos;

III - a aquisição de máquinas ou equipamentos usados, salvo nos casos em que o Comitê de Crédito, em caráter de excepcionalidade, assim delibere;

IV - construções civis, aquisição de máquinas e equipamentos fixos ao solo e demais benfeitorias que passem a integrar definitivamente imóveis de terceiros;

$V$ - a aquisição de terrenos ou de unidades já construídas ou em construção;

$V I$ - a aquisição de veículos de passeio; $e$

VII - gastos gerais de administração. (DISTRITO FEDERAL, 2005)

\subsubsection{Limites de Concessão, Progressividade e Taxas Aplicadas}

Considerando a preocupação com a sustentabilidade do empreendimento e buscando evitar o endividamento superior à capacidade de pagamento do proponente ao crédito a legislação estabeleceu tetos de concessões, bem como

Tabela 3 - Tetos de Concessão para Crédito Urbano e Rural

\begin{tabular}{|l|l|}
\hline Pessoa Física (Empreendimento Informal) & Até $\mathrm{R} \$ 22.600,00$ \\
\hline Pessoa Jurídica (Empreendimento Formal) & Até $\mathrm{R} \$ 45.200,00$ \\
\hline Cooperativa Urbana & Até $\mathrm{R} \$ 66.000,00$ \\
\hline Produtor Rural & Até $\mathrm{R} \$ 30.344,00$ \\
\hline Cooperativa Rural & Até $\mathrm{R} \$ 66.000,00$ \\
\hline
\end{tabular}

Fonte: Distrito Federal (2005)

A progressividade nos empréstimos concedidos constitui um incentivo dinâmico fundamental à administração do risco das operações de microcrédito. Tipicamente, os empréstimos começam com valores reduzidos, e, conforme haja assiduidade nos pagamentos, os montantes aumentam. A repetição das operações permite acúmulo de informação sobre o cliente. Ademais, havendo progressividade, a ameaça de corte nos futuros empréstimos tem maior peso, pois os tomadores 
podem perceber que, se deixarem de cumprir suas obrigações, deixarão de receber valores maiores do que aqueles inicialmente liberados.

Tabela 4 - Progressividade de Valores Concedidos na Área Urbana

\begin{tabular}{|c|c|c|c|c|}
\hline \multirow{2}{*}{ Progressividade } & \multirow{2}{*}{$\%$} & \multicolumn{3}{|c|}{ Valores Máximos Concedidos ( $\mathrm{R} \$$ ) } \\
\hline & & Informais & Formais & Cooperativa \\
\hline 1ํEmpréstimo & $15 \%$ & Até $3.390,00$ & Até $6.780,00$ & Até $9.900,00$ \\
\hline $2^{\circ}$ Empréstimo & $30 \%$ & Até $6.780,00$ & Até $13.560,00$ & Até $19.800,00$ \\
\hline 3 Empréstimo & $50 \%$ & Até $11.300,00$ & Até $22.600,00$ & Até $33.000,00$ \\
\hline 4ํㅡㄹ Eméstimo & $75 \%$ & Até $16.950,00$ & Até $33.900,00$ & Até $49.500,00$ \\
\hline 5 Empréstimo & $100 \%$ & Até $22.600,00$ & Até $45.200,00$ & Até $66.000,00$ \\
\hline
\end{tabular}

Tabela 5 - Progressividade de Valores Concedidos na Área Rural

\begin{tabular}{|c|c|c|c|}
\hline \multirow{2}{*}{ Progressividade } & \multirow{2}{*}{$\%$} & \multicolumn{2}{|c|}{ Valores Máximos Concedidos (R\$) } \\
\cline { 3 - 4 } & & Produtor & Cooperativa \\
\hline $1^{0}$ Empréstimo & $50 \%$ & Até $15.172,00$ & Até $33.000,00$ \\
\hline $2^{0}$ Empréstimo & $75 \%$ & Até $22.758,00$ & Até $49.500,00$ \\
\hline $3^{\circ}$ Empréstimo & $100 \%$ & Até $30.344,00$ & Até $66.000,00$ \\
\hline
\end{tabular}

Fonte: Distrito Federal (2005)

Tabela 6 - Prazos

\begin{tabular}{|l|l|}
\hline Capital de Giro Urbano & Até 36 meses para pagar, mais carência de até 3 meses. \\
\hline $\begin{array}{l}\text { Investimento } \\
\text { Urbano }\end{array}$ & Até 36 meses para pagar, mais carência de até 12 meses. \\
\hline Crédito Misto Urbano & $\begin{array}{l}\text { Capital de giro: Até } 12 \text { meses sem carência } \\
\text { Investimento: Até } 36 \text { meses, mais carência de até } 12 \text { meses }\end{array}$ \\
\hline Investimento Rural & Até 48 meses para pagar, mais carência de até 24 meses. \\
\hline Custeio Rural & Até 12 meses para pagar, mais carência de até 12 meses. \\
\hline
\end{tabular}

Fonte: Distrito Federal (2005)

Embora historicamente os pagamentos semanais ou quinzenais sejam mais comuns, a metodologia de microcrédito do Programa Prospera preveê conforme legislação específica a periodicidade mensal dos pagamentos. 
Tabela 7 - Taxas de Juros Praticadas

\begin{tabular}{|c|c|c|c|}
\hline Carteira & Modalidade de Crédito & Encargos Anuais & Encargos Mensais \\
\hline \multirow{2}{*}{ Crédito Urbano } & Capital de Giro & $1,5 \%$ aa + TJLP & $0,72 \% \mathrm{am}$ \\
\cline { 2 - 4 } & Investimento & $1 \%$ aa + TJLP & $0,68 \% \mathrm{am}$ \\
\hline \multirow{2}{*}{ Crédito Rural } & Custeio & $2 \%$ aa & $0,16 \% \mathrm{am}$ \\
\cline { 2 - 4 } & Investimento & $3 \%$ aa & $0,24 \% \mathrm{am}$ \\
\hline \multirow{2}{*}{ Beneficiários especiais } & $\begin{array}{c}\text { Capital de Giro } \\
\text { e/ou } \\
\text { Investimento }\end{array}$ & $5 \%$ aa & $0,40 \% \mathrm{am}$ \\
\hline
\end{tabular}

Fonte: Distrito Federal (2005). Taxa mensal calculada em nov/2016

A Taxa de Juros de Longo Prazo - TJLP tem período de vigência de um trimestre-calendário e é calculada a partir dos seguintes parâmetros:

I - meta de inflação calculada pro rata para os doze meses seguintes ao primeiro mês de vigência da taxa, inclusive, baseada nas metas anuais fixadas pelo Conselho Monetário Nacional;

II - prêmio de risco.

A TJLP é fixada pelo Conselho Monetário Nacional e divulgada até o último dia útil do trimestre imediatamente anterior ao de sua vigência. Em moedas contratuais, a TJLP, expressa em percentual ao ano. 


\section{Tabela 8 - Evolução da TJLP em 2016}

\begin{tabular}{|c|c|}
\hline Trimestre & (\% a.a.) \\
\hline outubro a dezembro & $7,5 \%$ \\
\hline julho a setembro & $7,5 \%$ \\
\hline abril a junho & $7,5 \%$ \\
\hline janeiro a março & $7,5 \%$ \\
\hline
\end{tabular}

Fonte: BNDES

\subsubsection{Rede de Atendimento}

Por se tratar de um microcrédito mantido com recurso públicos do Distrito Federal, o Programa Prospera é vinculado à Secretaria de Estado de Trabalho do Distrito Federal a qual é responsável pela operacionalização do microcrédito na área urbana, e com cooperação da Secretaria de Estado de Agricultura do Distrito Federal no que compete às concessões da área rural.

De forma geral a Secretaria de Trabalho é responsável pelas políticas públicas de geração de emprego e renda e empreendedorismo, entre elas a política de microcrédito, conforme se verifica em seu regimento.

\section{[...]}

Art. XXo À Secretaria de Estado do Trabalho e do Empreendedorismo do Distrito Federal - SETRAB, órgão da administração direta, diretamente subordinada ao Governador do Distrito Federal, compete:

I - propor, articular, planejar, implementar e acompanhar políticas públicas voltadas para trabalho, 
para a população do Distrito Federal;

II - implementar sistema público de emprego;

III - promover programas e ações voltadas à formação, aperfeiçoamento e desenvolvimento profissional para os beneficiários dos programas sociais e grupos sociais vulneráveis;

IV - desenvolver ações para os setores da economia solidária, com vistas à geração de trabalho e renda;

$V$ - apoiar iniciativas de micro e pequenos empreendedores individuais ou organizados, em associações e cooperativas, com vistas à geração de trabalho e renda; $e$

VI - contribuir na consolidação de alternativas de trabalho, emprego e renda aos beneficiários do Plano pela Superação da Extrema Pobreza do Distrito Federal - "DF sem Miséria”, por intermédio de atividades de capacitação e qualificação profissional, do estímulo à concessão de microcrédito, do fomento ao empreendedorismo, ao associativismo, ao cooperativismo e à economia solidária e criativa; (Grifo nosso)

VI - realizar o acompanhamento sistemático do mercado de trabalho no Distrito Federal.

[...] (SETRAB, 2016)

O Decreto № 25.745, de 11 de abril de 2005 e resoluções legais posteriores elencam as atribuições destas Secretarias.

\section{$[\ldots]$}

Art. 15. A operacionalização dos empréstimos e financiamentos da carteira de crédito urbano é de responsabilidade da Secretaria de Estado de Trabalho, a quem compete:

I- identificar a clientela e receber as solicitações de crédito;

II - verificar o enquadramento da clientela nos critérios definidos pelo Conselho de Administração do FUNGER/DF, conferindo os dados pessoais dos proponentes;

III - proceder a inscrição dos inadimplentes do FUNGER/DF na dívida ativa da Fazenda Pública do Distrito Federal;

IV - realizar visitas aos empreendimentos para elaboração de laudos técnicos de viabilidade econômica, a serem submetidos à aprovação do Comitê de Crédito; 
$V$ - viabilizar a capacitação, o treinamento gerencial e a orientação e assistência técnica aos empreendedores;

$V I$ - disponibilizar os recursos para efetivar os créditos aprovados pelo Comitê de Crédito;

VII - acompanhar e avaliar os empreendimentos financiados, visando ao cumprimento dos objetivos do FUNGER/DF;

VIII - encaminhar, regularmente, informações sobre todas as atividades desenvolvidas ao Conselho de Administração do FUNGER/DF;

IX-acompanhar, efetuar aviso de cobrança e controlar os níveis de inadimplência dos contratos vigentes; $e$

$X I$ - solicitar ao agente financeiro pesquisas cadastrais dos proponentes e coobrigados nos órgãos de proteção ao crédito.

Art.16. A operacionalização dos créditos da carteira de crédito rural é de responsabilidade conjunta da Secretaria de Estado de Trabalho e da Secretaria de Estado de Agricultura, competindo:

I - à Secretaria de Estado de Trabalho:

a) disponibilizar os recursos para efetivar os créditos aprovados pelo Comitê de Crédito; e

b) encaminhar, regularmente, informações sobre todas as atividades desenvolvidas ao Conselho de Administração do FUNGER/DF.

II - à Secretaria de Estado de Agricultura do Distrito Federal:

a) identificar a clientela e receber as solicitações de crédito;

b) verificar o enquadramento da clientela nos critérios definidos pelo Conselho de Administração do FUNGER/DF, conferindo os dados pessoais dos proponentes;

d) elaborar projeto de viabilidade econômica dos empreendimentos rurais;

e) enviar os projetos, acompanhados de laudo de viabilidade, a serem submetidos à aprovação do Comitê de Crédito;

f) comunicar aos interessados as decisões do Comitê de Crédito;

g) acompanhar e avaliar os empreendimentos financiados, visando o cumprimento dos objetivos do FUNGER/DF;

h) encaminhar relatórios de acompanhamento e avaliação à Secretaria de Estado de Trabalho;

i) acompanhar, efetuar aviso de cobrança e controlar os níveis de inadimplência dos contratos vigentes; 
j) realizar as renegociações das dívidas, em conformidade com as normas do Conselho de Administração do FUNGER/DF e encaminhar as decisões para conhecimento e controle da Secretaria do Trabalho; e

l) viabilizar a capacitação, o treinamento gerencial e a orientação e assistência técnica aos empreendedores.

m) solicitar ao agente financeiro pesquisa cadastral dos proponentes e coobrigados aos créditos da carteira rural nos órgãos de proteção ao crédito.

$[\cdots]$

Desta forma, todo o atendimento do Programa é realizado por servidores públicos de carreira ou servidores em cargo comissionado que executam os diversos atos administrativos conforme competências específicas, determinas em regimento próprio.

A estrutura funcional que operacionaliza o Programa é composto por 10 unidades orgânicas, conforme organograma apresentado a seguir.

\section{Figura 4 - Organograma da Secretaria de Trabalho}

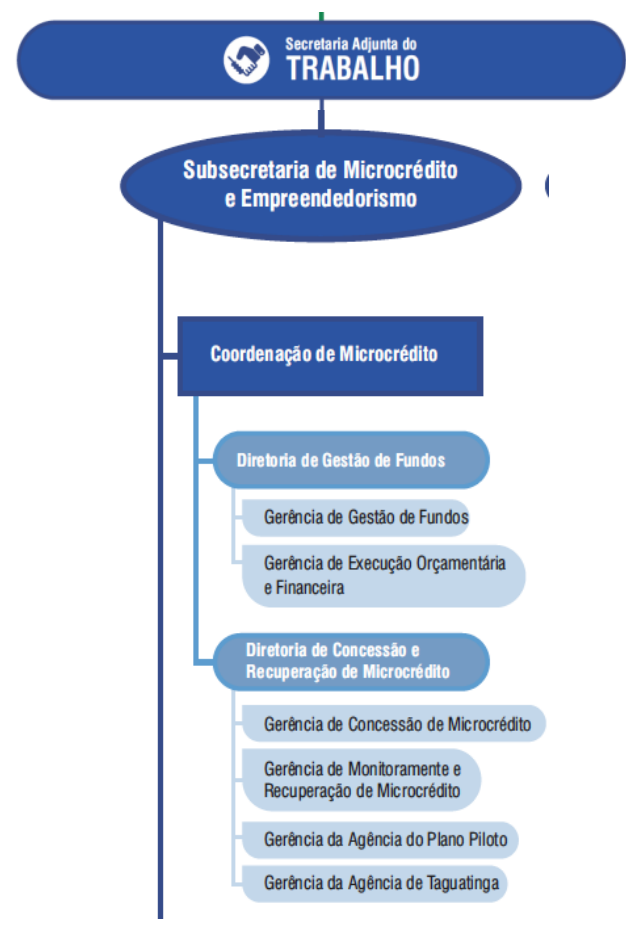

Fonte: SETRAB (2016), com recortes.

A linha de frente de atendimento ao empreendedor que busca o microcrédito 
são as duas Agencias de Microcrédito existentes, uma no Plano Piloto e outra em Taguatinga, responsáveis por processo os pedidos de concessão conforme divisão geográfica por proximidade. Com isso, empreendedores domiciliados em Brasília são atendidos pela Agência do Plano Piloto, enquanto os domiciliados em Samambaia são direcionados à Agência de Taguatinga. $O$ atendimento pode ser realizado também em Agências do Trabalhador espalhadas pelo Distrito Federal, mas somente a título de pré-cadastro.

Conforme previsão em legislação específica 0 agente financeiro dos recursos do FUNGER/DF é o Banco de Brasília S/A - BRB

\subsubsection{Processo de Concessão}

A metodologia adotada pelo Programa Prospera prevê a simplificação do processo de concessão, promovendo contato direto entre os interessados e a instituição de concessão, que não se trata de um banco, mas uma agência de serviço público aonde o cidadão possa recorrer sempre que necessário.

O processo de concessão pode ser resumido em 6 etapas:

\section{Etapa 1: Inscrição no Programa}

O empreendedor pessoalmente se dirige a uma agência de atendimento público. Nesta fase, o proponente recebe detalhes do programa e se desejar inicia o processo apresentando documentos pessoais e empresariais se for o caso.

\section{Etapa 2: Verificação Cadastral}

Conforme legislação específica, os dados cadastrais são submetidos a verificação junto à Fazenda Pública do Distrito Federal e órgãos de proteção ao crédito, quando não se tratar de público com atendimento diferenciado conforme exposto anteriormente. 
Um agente de crédito realiza visita in loco no empreendimento, podendo ser o endereço comercial ou residencial conforme o caso. A etapa de visita é uma exigência da legislação específica para habilitação ao crédito.

Etapa 4: Análise e Preparação da Proposta

O agente de crédito elabora proposta de crédito, a qual é negociada com o proponente em termos de valores e prazos.

Etapa 5: Aprovação e Contratação da Proposta

$\mathrm{O}$ agente de crédito, uma vez autorizado pelo empreendedor solicitante submete a proposta a Comitê de Julgamento empossados conforme previsão legal.

Etapa 6: Acompanhamento e Monitoramento

$\mathrm{O}$ agente de crédito mantém contato com o empreendedor que assumiu o crédito afim de averiguar a correta aplicação dos recursos, bem como o desenvolvimento do empreendimento, e se necessário, efetuar cobranças visando sempre a fidelização do empreendedor ao Programa. 


\section{Figura 5 - Fluxograma do Processo de Concessão}

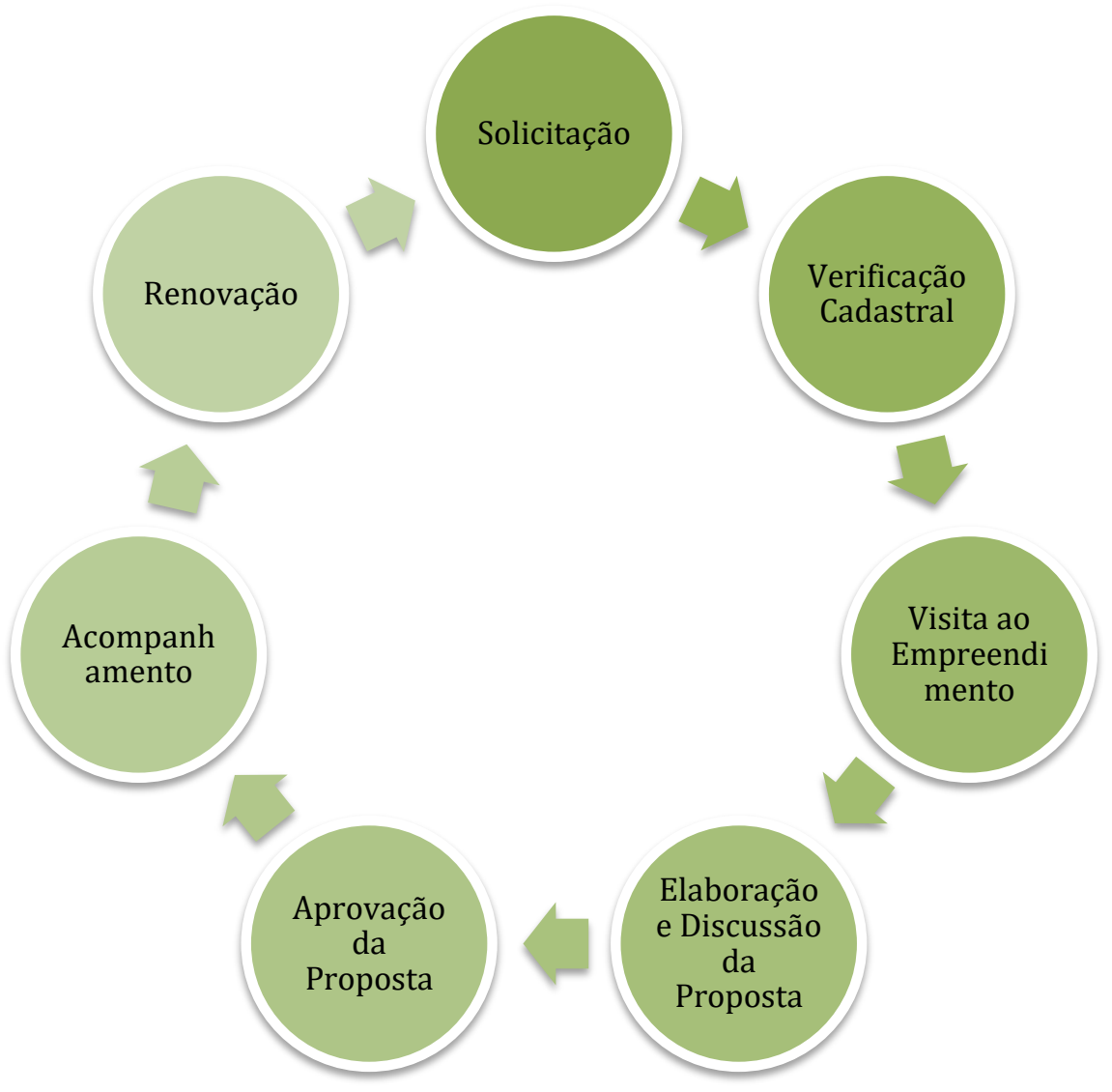

\subsubsection{O Prospera em Números}

Para esta seção, faremos a limitação dos dados, sem levar em conta os 21 anos de existência do Programa de microcrédito do Governo do Distrito Federal considerando sua criação com a Lei Complementar № 005, de 14 de Agosto de 1995. Isso se deve a ausência de informações disponíveis no período anterior a 2006, com exceção do ano de 2001.

Hessel (2011) apresenta dados quantitativos das concessões de microcrédito produtivo orientado do Programa Prospera entre os períodos de 2006 a 2010, conforme segue 
Tabela 9 - Volume de Concessões em 2001, 2006 a 2010 (R\$)

\begin{tabular}{|c|c|r|}
\hline Ano & $\begin{array}{c}\text { Quantidade de } \\
\text { Contratos }\end{array}$ & Valor Liberado (R\$) \\
\hline 2001 & 2090 & $5.800 .000,00$ \\
\hline 2006 & 4738 & $35.739 .191,00$ \\
\hline 2007 & 1098 & $7.046 .788,39$ \\
\hline 2008 & 2192 & $15.074 .430,18$ \\
\hline 2009 & 1816 & $14.858 .926,52$ \\
\hline 2010 & 831 & $5.846 .012,95$ \\
\hline
\end{tabular}

Fonte: BRB, 2001; Hessel, 2011

Com isso, o Programa Prospera liberou mais de $R \$ 84$ milhões a pelo menos 10.765 tomadores pessoa física ou jurídica ao longo de 6 anos.

Há um lapso de informações a respeito do volume de concessões entre os anos de 1995 a 2000 e 2002 a 2005 quando o Programa ainda era regido sob a Lei Complementar do FULSON/DF, e o mesmo acontece entre os anos de 2011 e 2014 sob a Lei Complementar do FUNGER/DF. As informações são retomadas em 2015 com maiores detalhes das características das concessões. 
Tabela 10 - Volume de Concessões em 2015 (R\$)

\begin{tabular}{|c|c|c|c|c|c|}
\hline Área & Finalidade & Tomador & $\mathrm{R} \$$ & $\%$ & $\%$ \\
\hline \multirow{4}{*}{ Urbana } & \multirow{2}{*}{ Capital de Giro } & Formal & $1.604 .270,00$ & $34,63 \%$ & \multirow{4}{*}{$45,53 \%$} \\
\hline & & Informal & $383.880,00$ & $8,29 \%$ & \\
\hline & \multirow{2}{*}{ Investimento } & Formal & $98.599,00$ & $2,13 \%$ & \\
\hline & & Informal & $21.993,97$ & $0,47 \%$ & \\
\hline \multirow{4}{*}{ Rural } & \multirow{2}{*}{ Custeio } & Formal & - & $0,00 \%$ & \multirow{4}{*}{$54,47 \%$} \\
\hline & & Informal & $2.108 .742,97$ & $45,53 \%$ & \\
\hline & \multirow{2}{*}{ Investimento } & Formal & - & $0,00 \%$ & \\
\hline & & Informal & $414.452,15$ & $8,95 \%$ & \\
\hline Total & & & $4.631 .938,09$ & $100,00 \%$ & $100 \%$ \\
\hline
\end{tabular}

Fonte: Secretaria de Trabalho

Tabela 11 - Categoria de Tomador por Registro em 2015

\begin{tabular}{|c|c|c|}
\hline Categoria & Liberações & $\%$ \\
\hline Formal & 145 & $58 \%$ \\
\hline Informal & 103 & $42 \%$ \\
\hline Total & $\mathbf{2 4 8}$ & $\mathbf{1 0 0} \%$ \\
\hline
\end{tabular}

Fonte: Secretaria de Trabalho

Tabela 12 - Classificação por Sexo em 2015

\begin{tabular}{|c|c|c|}
\hline Categoria & Liberações & $\%$ \\
\hline Homens & 99 & $40 \%$ \\
\hline Mulheres & 149 & $60 \%$ \\
\hline Total & $\mathbf{2 4 8}$ & $\mathbf{1 0 0} \%$ \\
\hline
\end{tabular}

Fonte: Secretaria de Trabalho

Os segmentos atendidos foram Agricultura, Artesanato, Comércio, Indústria, Pecuária e Serviços. É importante ressaltar que em 2015 as concessões foram suspensas por mais de 9 meses. 
Tabela 13 - Empregos Gerados/Mantidos em 2015

\begin{tabular}{|c|c|c|}
\hline Empregos & Liberações & $\%$ \\
\hline Gerados & 61 & $11 \%$ \\
\hline Mantidos & 494 & $89 \%$ \\
\hline Total & $\mathbf{5 5 5}$ & $\mathbf{1 0 0} \%$ \\
\hline
\end{tabular}

Fonte: Secretaria de Trabalho

Em 2016, verifica-se que foi mantida a sistemática de registros adotada em 2015 facilitando a demonstração do volume de concessões como segue.

Tabela 14 - Volume de Concessões em 2016 (R\$)

\begin{tabular}{|c|c|c|c|c|c|}
\hline Área & Finalidade & Tomador & $\mathbf{R} \$$ & $\%$ & $\%$ \\
\hline \multirow{4}{*}{ Urbana } & \multirow{2}{*}{ Capital de Giro } & Formal & $3.663 .239,82$ & $40,40 \%$ & \multirow{4}{*}{$54,06 \%$} \\
\hline & & Informal & $788.606,93$ & $8,70 \%$ & \\
\hline & \multirow{2}{*}{ Investimento } & Formal & $422.130,48$ & $4,66 \%$ & \\
\hline & & Informal & $27.763,07$ & $0,31 \%$ & \\
\hline \multirow{4}{*}{ Rural } & \multirow{2}{*}{ Custeio } & Formal & $31.647,00$ & $0,35 \%$ & \multirow{4}{*}{$45,94 \%$} \\
\hline & & Informal & $1.780 .493,69$ & $19,64 \%$ & \\
\hline & \multirow{2}{*}{ Investimento } & Formal & - & $0,00 \%$ & \\
\hline & & Informal & $2.353 .128,93$ & $25,95 \%$ & \\
\hline Total & & & $9.067 .009,92$ & $100,00 \%$ & $100 \%$ \\
\hline
\end{tabular}

Fonte: Secretaria de Trabalho

Tabela 15 - Categoria de Tomador por Registro em 2016

\begin{tabular}{|c|c|r|}
\hline Categoria & Liberações & \multicolumn{1}{|c|}{$\%$} \\
\hline Formal & 360 & $49 \%$ \\
\hline Informal & 371 & $51 \%$ \\
\hline Total & $\mathbf{7 3 1}$ & $\mathbf{1 0 0 \%}$ \\
\hline
\end{tabular}

Fonte: Secretaria de Trabalho 
Tabela 16 - Classificação por Sexo em 2016

\begin{tabular}{|c|c|c|}
\hline Categoria & Liberações & $\%$ \\
\hline Homens & 335 & $46 \%$ \\
\hline Mulheres & 396 & $54 \%$ \\
\hline Total & $\mathbf{7 3 1}$ & $\mathbf{1 0 0 \%}$ \\
\hline
\end{tabular}

Fonte: Secretaria de Trabalho

As concessões de 2016 refletem os dados compiladas até o mês de outubro. Os segmentos atendidos foram Agricultura, Artesanato, Comércio, Indústria, Pecuária e Serviços. Durante 3 meses de 2016 não foram realizadas concessões.

Tabela 17 - Empregos Gerados/Mantidos em 2016

\begin{tabular}{|c|c|c|}
\hline Empregos & Liberações & $\%$ \\
\hline Gerados & 335 & $46 \%$ \\
\hline Mantidos & 396 & $54 \%$ \\
\hline Total & $\mathbf{7 3 1}$ & $\mathbf{1 0 0 \%}$ \\
\hline
\end{tabular}

Fonte: Secretaria de Trabalho

Por fim, somando os valores concedidos ao longos dos 8 anos registrados, ainda que sem continuidade, tem-se um aporte total de $\mathrm{R} \$ 98.064 .297,05$ na economia repassados a 13.744 empreendedores do Distrito Federal. 


\section{CONSIDERAÇÕES FINAIS E PERSPECTIVAS}

Este trabalho realizou uma descrição e análise do Programa Prospera de Microcrédito Produtivo e Orientado do Governo do Distrito Federal, em funcionamento desde 1995. Tivemos com perspectiva inicial a elaboração de um referencial teórico bibliográfico levando em conta os estudos realizados a respeito do microcrédito do Brasil e no mundo.

Essa base teórica permitiu construir a hipótese sobre a pertinência do Programa Prospera enquanto microcrédito bem como sua contribuição para o alavancagem do empreendedorismo no Distrito Federal, enquanto política pública de desenvolvimento utilizada como alternativa para redução da pobreza com aumento de emprego e renda.

Verificou-se que o microcrédito está incluído nas alternativas microfinanças, uma vez que está destinado basicamente à concessão de empréstimos de pequeno valor aos empreendedores formais e informais que em geral têm dificuldade para ingressar no sistema financeiro tradicional de crédito. Considerando que os programas de microcrédito utilizam metodologias diferencias de análise e concessão voltadas para os segmentos de empreendedores mais carentes do mercado produtivo e de serviço, com taxas de juros menores, tem sido defendido amplamente como estratégia de política pública.

Estudiosos defendem que o microcrédito é um instrumento de combate à pobreza, por permitir que pequenos empreendedores tenham acesso ao crédito sem sofrerem com as taxas de juros abusivas. Como arranjo contratual do microcrédito reduz o custo do dinheiro ao tomador final e amplia a oferta de crédito na economia, tal política seria indispensável o Brasil considerando a contribuição das micro e pequenas empresas para a composição do PIB, bem com a geração de emprego e renda.

Outras grandes inovações trazidas pelo microcrédito foram a concessão de pequenos valores, atendimento mediado por agentes de crédito, possibilidade de 
aval solidário sem garantias próprias ou de terceiros, e ainda o acompanhamento e orientação permanentes.

A partir do estudo realizado sobre o Programa Prospera, verificou-se que o público-alvo se enquadra nos seguimentos historicamente atendidos pelas politicas de microcrédito no Brasil e no mundo, uma vez que a legislação específica estabelece 0 atendimento a empreendedores informais como feirantes, ambulantes, prestados de serviços, profissionais liberais como também a empreendimentos formalizados como micro e pequenas empresas.

O Programa incluiu, conforme previsão legal, os recém-formados no rol de possíveis tomadores, com atendimento diferenciado, pois como indica Santiago apud Matos et al (2014) "...são raríssimos aqueles que direcionam empréstimos para microprodutores iniciantes."

A aceitação de empreendimentos iniciantes é um fator importante para a diminuição do desemprego uma vez que Lima e Gomes (2010) indicam que o crescimento do desemprego entre os mais escolarizados tem promovido discussões acerca da eficácia do diploma como uma solução para o desemprego. E Tomio e Hoeltgebaum (2001) afirmam que grande maioria dos alunos egressos dos cursos superiores atuarão em seu futuro nas micro, pequenas e médias empresas, seja como empregado ou como dono de um negócio, e ainda verificaram em seu estudo que há elevado interesse dos estudantes universitários brasileiros em abrir seu negócio.

Outro aspecto positivo que deve ser levantado em relação ao Programa é o atendimento a cidadãos empreendedores participantes de programas sociais dos governos distritais ou federais, pois conforme defendem Soares e Sátyro (2009) as portas de saída tem papel primordial nos programas sociais, e portanto é necessário que estes programas estejam intimamente conectados à oferta de capacitação, treinamento, aconselhamento familiar, microcrédito, desenvolvimento local e outros programas cujo objetivo seja capacitar a família para que ela escape da pobreza pelos seus próprios meios, como historicamente tem sido a premissa das inciativas de microcrédito. 
No ambiente institucional há discussões em torno dos limites de valores que podem ser concedidos que superariam em muito os valores historicamente vinculados nos programas de microcrédito, que variam de $R \$ 100,00$ a $R \$ 1.000,00$. Em relação a isso, Braga e Toneto Jr. (2000) declaram que cada agente financeiro tem suas próprias definições sobre linhas e formas de atuação e são eles em última instância que definem quanto e para quem os recursos serão liberados.

Sobre isso ainda é importante salientar que como visto anteriormente o Estatuto da Micro e Pequena Empresa (LC 123/2006) de âmbito nacional ampara sob seu arcabouço empreendimentos com faturamento de até 4.800.000,00 (quatro milhões e oitocentos mil reais), para as quais o Estado deve proporcionar linha de crédito facilitadas. E deve-se levar em conta que ao longos desses 21 anos de existência do Programa Prospera e mais de 30 anos da proliferação do microcrédito pelo mundo, a realidade econômica mundial foi alterada positivamente, ampliando as transações comerciais dos empreendimentos para os quais valores de $\mathrm{R} \$ 1.000,00$ poderiam ser considerados insuficientes para alcançar os objetivos esperados com a aquisição do crédito. E no Distrito Federal, especialmente os negócios tem se desenvolvido

As taxas de juros praticadas pelo Programa Prospera também servem para ampliar a percepção do mesmo como uma política pública de microcrédito, visto que como já comentado por Estigara (2008), o próprio Grameen Bank que levou notoriedade ao microcrédito aplicava taxas anuais de $20 \%$ que superam a taxa máxima de 5\%aa, ou ainda em relação ao PNMPO que como marco regulatório legal indica taxas máximas de $4 \%$ mensais.

Tomando por base os dados compilados de 2016, que apresentam maior nível de detalhes e em um período de tempo maior, verifica-se que o Programa Prospera tem realizado atendimento nas cidades e no campo como já demonstram os estudos sobre o microcrédito a partir das experiências no Brasil e fora dele. Observa-se também que formais e informais receberam o reforço creditício do Programa, no entanto, em relação ao período analisado houve mais atendimentos ao setor informal demonstrando 0 atendimento às camadas mais fragilizadas dos 
empreendedores.

A geração ou manutenção de empregos também são um sinal importante da concessão de microcrédito pelo Programa, uma vez que 731 postos de trabalho foram possibilitados mesmo, evitando ampliar o percentual de desocupados do Distrito Federal, ainda que as ocupações geradas não reflitam necessariamente ocupações formalizadas, porém garantem renda às pessoas envolvidas que podem ser o empreendedor com seus familiares ou pessoas contratadas por estes. É sempre importante lembrar que um empreendimento que se sustenta financeira é garantia de que pelo menos o próprio empreendedor está obtende renda com sua atividade.

As mulheres também aparecem como grandes tomadoras de crédito uma vez que no programa superam o número de solicitações e concessões aprovadas. Historicamente as mulheres sempre foram o público-alvo prioritário do microcrédito em pelo seu papel fundamental na administração familiar.

Tomando por referencia o Plano Plurianual do Distrito Federal para o quadriênio 2012-2015 (DISTRITO FEDERAL, 2011) verifica-se que as metas estabelecidas para o ano de 2015 ficaram muito aquém do esperado uma vez que projetava 6.000 concessões com volume total de $R \$ 24$ milhões e foram realizadas apenas 248 concessões totalizando cerca de $\mathrm{R} \$ 4$ milhões.

O Governo do Distrito Federal demonstra interesse na permanência do Programa de Microcrédito Prospera, bem como consciência da sua importância conforme se verifica em seu Plano Plurianual para o quadriênio 2016-2019 quando declara

"A clientela desse Programa é preferencialmente constituída por empreendedores mais vulneráveis e excluídos do sistema bancário tradicional, e que o diferencial do Programa de Microcrédito são os encargos cobrados, muito abaixo aos praticados pelo mercado. Os empreendimentos atendidos no Programa de Microcrédito têm como característica o emprego da mão-de-obra familiar, não formalizado, ou seja, sem carteira de trabalho assinada.

Apesar disto, não resta dúvida que programas dessa natureza são 
de grande importância para o alcance do objetivo específico de geração de trabalho, emprego e renda do Distrito Federal e RIDE/DF. O público a ser atingido é composto de empreendedores informais, empreendedores individuais, microempresas e empresas de pequeno porte, produtores rurais da agricultura familiar e cooperativas de trabalho das áreas urbanas ou rurais.

$[\ldots]$

O Programa de Microcrédito se constitui de fato numa política pública importante e indispensável, com potencial para contribuir para 0 desenvolvimento socioeconômico do Distrito Federal, por meio da geração/manutenção de emprego e renda.

A conjuntura econômica atual, marcadamente recessiva e com sérias restrições ao crédito, devido principalmente à elevação dos juros dos empréstimos e financiamentos, com reflexos diretos nos pequenos negócios $e$, por conseguinte, em sua capacidade de manter e gerar ocupações de trabalho aponta para a necessidade de fortalecimento do Programa de Microcrédito como política pública de emprego e renda, para o apoio aos pequenos empreendedores, tendo como principal desafio garantir a sobrevivência do setor e a manutenção das ocupações e empregos do setor produtivo de pequeno porte, historicamente reconhecido como grande empregador de mão-de-obra, mas que não encontra contrapartida no sistema bancário tradicional." (DISTRITO FEDERAL, 2015)

Reconhece ainda a necessidade de prover infraestrutura adequada para a execução do Programa quando declara que

"[...] para que os objetivos institucionais e as metas previstas nesse PPA possam ser atingidos, é indispensável o fortalecimento da estrutura de atendimento do Programa de Microcrédito da SETRAB/FUNGER-DF, dotando-o com o quantitativo adequado de servidores, devidamente capacitados, tanto para atuar nas funções administrativas internas quanto na de Agentes de Crédito, e também de sua estrutura de transporte, com um número de veículos suficientes. "(DISTRITO FEDERAL, 2015)

O reconhecimento das necessidades estruturais do Programa parecem ser essenciais se considerarmos que as metas projetados para o novo quadriênio 2016 2019 apresentam números audaciosos com 5.569 concessões somando 
$\mathrm{R} \$ 55.692 .000,00$ que se comparados aos números atingidos em 2016 representam uma execução de $13 \%$ do total previsto.

A sistematização da compilação de dados para análises quantitativas e qualitativas das concessões realizadas é imprescindível para verificação do alcance dos objetivos do Programa em termos de eficiência e eficácia pois possibilitam cruzar os dados com outras fontes de informações como os registros empresarias disponibilizados pela Secretaria de Fazenda que apresentam classificação das diversas tipos de empreendedores disponíveis em seu cadastro, banco de dados do Cadastro Geral de Empregos entre outros. Isso associado à correta exploração do banco de dados disponível sob guarda da instituição bancária que atua como agente financeiro previsto legalmente. 


\section{REFERENCIAL}

\section{Livros, Dissertações, Artigos e Sítios da Internet}

APEMEC, Microcrédito dos Bancos Públicos cresce com subvenção. Disponível em: < http://apemec.com.br/view_news.php?id=1954 >. Acesso em: 10 nov. 2016

ARAÚJO, Elaine Aparecida. Análise do desempenho financeiro e social das instituições de microcrédito brasileiras. UFLA Lavras, 2012.

BARONE, Francisco Marcelo e SADER, Emir. Acesso ao crédito no Brasil: evolução e perspectivas. Revista da Admministração Pública Vol.42 N.6 Rio de Janeiro, 2008

BARONE, F. M.; DANTAS, V.; LIMA, P. F.; REZENDE, V. Introdução ao microcrédito. Brasília: Conselho da Comunidade Solidária, 2002.

BRAGA, Márcio Bobik e TONETO JR, Rudinei. Microcrédito: aspectos teóricos e experiências. Revista Análise Econômica , UFRGS, 2000

BRASIL, MTE (2016) Empreendedorismo: Programa Nacional de Microcrédito $\begin{array}{llll}\text { Produtivo Orientado (PNMPO). Disponível em } & \end{array}$ <http://trabalho.gov.br/empreendedorismo/pnmpo> Acessado em 20 nov. 2016

BRASIL. Lei no 8.029, de 12 de abril de 1990: Programa Nacional de Microcrédito Produtivo Orientado - PNMPO. Brasília, 2005

BRASIL. Lei no 11.110, de 25 de abril de 2005. Diário Oficial da República Federativa do Brasil, Poder Executivo, Brasília, 2005.

BRASIL, Relatório de gestão 2011. Brasília, 2012.

BRB. Relatório da Administração, 2001. Disponível em < https://www.google.com.br/url?sa=t\&rct=j\&q=\&esrc=s\&source=web\&cd=4\&cad=rja\& uact=8\&ved=0ahUKEwjJob_xzOTQAhUDj5AKHW81DocQFggpMAM\&url=http\%3A\% 2F\%2Fwww.infoinvest.com.br\%2Fmodulos\%2Fdoc.asp\%3Farquivo\%3D01420010.w an\%26doc\%3Dian520.doc\%26language\%3Dptb\&usg=AFQjCNEnrvv0-vLcfvqlbW6a4QW0L7_ww\&sig2=SguJO3sTI2lljpQ7Niw43g> Acesso em 25 nov. 2016

BRONZATI, Aline. Banco do Brasil e Bradesco criam empresa para atuar em microcrédito. O Estado de São Paulo. 21 nov. 2014. Disponível em:

<http://economia.estadao.com.br/noticias/negocios,banco-do-brasil-e-bradescocriam-empresa-para-atuar-em-microcredito,1596335> Acesso em 10 nov. 2016 
CEBDS - Conselho Empresarial Brasileiro para o Desenvolvimento Sustentável. Rio de Janeiro, 2013

CODEPLAN. Potencial Empreendedor no Distrito Federal (1 $1^{\text {a }}$ Etapa) Emprego no Distrito Federal Segundo Posição na Ocupação. Codeplan. Brasília, 2015

COLODETI, Vicente de Paulo. Microcrédito : uma política social de redução da pobreza. 2011.

COSTANZI, Rogério Nagamine e PASSOS, Alessandro Ferreira dos. Programas de geração de emprego e renda com recursos do fundo de amparo ao trabalhador: evolução, avaliação e proposta de reformulação. IPEA, Brasília, 2005.

DISTRITO FEDERAL. Plano Plurianual 2016-2019. 31 dez. 2015. Brasília, 2015 Disponível em <http://www.seplag.df.gov.br/planejamento-eorcamento/planejamento-governamental/299-ppa-2016-2019.html> Acesso em 01 dez 2016

DISTRITO FEDERAL. Plano Plurianual 2012-2015. 31 dez. 2011. Brasília, 2011. Disponível em <http://www.seplag.df.gov.br/planejamento-eorcamento/planejamento-governamental/268-plano-plurianual-2013.html>. Acesso em 01 dez. 2016

DISTRITO FEDERAL. Lei Complementar № 005, de 14 e Agosto de 1995 (Funsol). 14 ago. 2015. Disponível em

$<$ http://www.fazenda.df.gov.br/aplicacoes/legislacao/legislacao/TelaSaidaDocumento .cfm?txtNumero $=5 \&$ txtAno $=1995 \& t x t T i p o=4 \& t x t P a r t e=.>$ Acesso em 20 nov. 2016

DISTRITO FEDERAL. Síntese de Informações Socioeconômicas, 2014. Companhia de Planejamento do Distrito Federal. Brasília, 2014.

EBC. BNDES muda regras para aumentar alcance do microcrédito. Valor Econômico, 2016. Disponível em:

http://memoria.ebc.com.br/agenciabrasil/noticia/2010-03-16/bndes-muda-regras-doprograma-de-microcredito-para-atingir-mais-microempreendedores $>$. Acesso em: 10 nov. 2016.

ESCOBAR, Edson Murilo (Org). Programa Providência: de Elevação da Renda Familiar - Relatório Anual 2015. 6 mar. 2016. Disponível em < http://programaprovidencia.org.br/wp-content/uploads/2014/05/Versa\%CC\%83oFinal-Providencia_Relatorio-2015-2.pdf.> Acesso em 20 nov. 2016

ESTRELLA, Juliana. Avaliando o microcrédito como uma política de redução de desigualdade de oportunidades e melhoria de bem-estar. Rio de Janeiro 2008 
ESTIGARA, Adriana. Desenvolvimento sustentável, democracia econômica e políticas públicas: uma análise a partir do microcrédito, PUC. Rio de Janeiro, 2008

HESSEL, Fernando de Oliveira. Gestão de desenvolvimento local e o uso do banco público como instrumento de gestão: Um estudo de caso sobre a atuação do BRB. Brasília, 2011.

KERSTENETZKY, Celia Lessa e PIMENTEL, Vinícius. Microcrédito: por que os bancos privados não bancam?. Textos para Discussão, UFF. Rio de Janerio, 2008

KOTESKI, Marcos Antonio . As Micro e Pequenas Empresas no Contexto Econômico Brasileiro. Revista da FAE. São Paulo, 2004

KRAYCHETE, Elsa Sousa. O Banco Mundial e o desenvolvimento das microfinanças em países da periferia capitalista 2005.

LIMA, Alynne Virginya de Queiroz e GOMES, Manoel William Ferreira. "Estou formado(a), e agora?". Cadernos de Pesquisa. São Luiz, 2010

LIMA, Shanna Nogueira. Microcrédito como política de geração de emprego e renda. BNDES, Rio de Janeiro, 2009

MACEDO, Mariano de Matos. GEM-Global Entrepreneurship Monitor Empreendedorismo no Brasil:2015 Curitiba: IBQP, 2015.

MANOS, Maria Geovania Lima. Sistema finaceiro e desenvolvimento econômico: o papel do microcrédito. Aracaju; Embrapa, 2006

MATOS, Franco de; MACAMBIRA, Júnior; CACCIAMALI. (org) A atividade e a política de microcrédito no Brasil : visões sobre sua evolução e futuros desafi os. Fortaleza : IDT, USP, 2014.

MICHAELIS, Dicionário Brasileiro de Língua Portuguesa. Disponível em: <http:// http://michaelis.uol.com.br/ >. Acesso em 25 de setembro de 2016.

MIGUEL, Antonia Celene,. Microcrédito no Brasil: Uma Agenda de Política Pública Para o Mercado de Microfinanças, 2012

NERI, Marcelo. Nanocrédito e combate à pobreza. In: (Org.). Microcrédito, o mistério nordestino e o Grameen brasileiro: perfil e performance dos clientes do CrediAmigo. Rio de Janeiro: Fundação Getúlio Vargas, 2008. 
NOBEL FOUNDATION. The Nobel Peace Prize 2006. Disponível em: $<$ http://www.nobelprize.org/nobel_prizes/peace/laureates/2006/>. Acesso em: 05 nov. 2016.

PUGA, Fernando Pimentel. Experiências de apoio às micro, pequenas e médias empresas nos Estados Unidos, na Itália e em Taiwan. Textos para Discussão, BNDES: Rio de Janeiro, 2000

RIBEIRO, Cristina Tauaf e CARVALHO, Carlos Eduardo. Do Microcrédito às Microfinanças: Desempenho Financeiro, Dependência de Subsídios e fontes de financiamento: uma contribuição à análise da experiência brasileira. São Paulo; FAPESP; EDUC, 2006.

RODRIGUES, Mateus. Justiça penhora bens de ex-deputado do DF por desvio de verbas de fundo. 17 nov. 2014. Disponível em < http://g1.globo.com/politica/noticia/2014/11/justica-penhora-bens-de-ex-deputado-dodf-por-desvio-de-verbas-de-fundo.html.> Acesso em 20 nov. 2016

\section{SEBRAE, Sobrevivência Das Empresas No Brasil Coleção Estudos E Pesquisas GEOR - Gestão Estratégica Orientada para Resultados. Coleção estudos e pesquisas. Sebrae. Brasíolia, 2013}

SEBRAE, Fatores Condicionantes e Taxa de Mortalidade de Empresas no Brasil- Relatório de Pesquisa. Sebrae Nacional. Brasília, 2004

SETRAB. Orgonagrama, Secretaria de Trabalho.

Disponível em <http://www.trabalho.df.gov.br/sobre-a-secretaria/a-secretaria.html>. Acesso em 20 nov. 2011

SILVA, Roberto Vilela de Moura. Disseminação DE Programas Públicos DE Microcrédito: o caso da Região Metropolitana de São Paulo. EASP/FGV.São Paulo, 2007

SIMEON, Nichter; GOLDMARK, Lara; FIORI, Anita. Entendendo as microfinanças no contexto brasileiro: Programa de Desenvolvimento Institucional. BNDES. Rio de Janeiro, 2002.

SOARES, Sergei e SÁTYRO, Natália. O Programa Bolsa Família: Desenho Institucional, Impactos e Possibilidades Futuras. Textos para Discussão. IPEA. Brasília, 2009

TOMIO, Dilson e HOELTGEBAUM, Marianne. A Problemática da Formação dos Administradores: O Empreendedorismo Como Alternativa de Adaptação no Ensino do Curso de Administração. EGEPE. Londrina. 2001

YUNUS, Muhammad; JOLIS, Alan. O Banqueiro dos Pobres. São Paulo: Ática, 2000. 